\title{
The Mitochondria-Targeted Antioxidant MitoQ Prevents Loss of Spatial Memory Retention and Early Neuropathology in a Transgenic Mouse Model of Alzheimer's Disease
}

\author{
Meagan J. McManus, ${ }^{2}$ Michael P. Murphy, ${ }^{3}$ and James L. Franklin ${ }^{1}$ \\ ${ }^{1}$ Department of Pharmaceutical and Biomedical Sciences, The University of Georgia College of Pharmacy, Athens, Georgia 30602, ${ }^{2}$ Center of Mitochondrial \\ and Epigenomic Medicine, Children's Hospital of Philadelphia, Colket Translational Research Building, Philadelphia, Pennsylvania 19104, and ${ }^{3}$ Medical \\ Research Council Mitochondrial Biology Unit, Cambridge CB2 0XY, United Kingdom
}

Considerable evidence suggests that mitochondrial dysfunction and oxidative stress contribute to the progression of Alzheimer's disease (AD). We examined the ability of the novel mitochondria-targeted antioxidant MitoQ (mitoquinone mesylate: [10-(4,5-dimethoxy-2methyl-3,6-dioxo-1,4-cycloheexadienl-yl) decyl triphenylphosphonium methanesulfonate]) to prevent AD-like pathology in mouse cortical neurons in cell culture and in a triple transgenic mouse model of $\mathrm{AD}(3 \mathrm{xTg}-\mathrm{AD})$. Mito Q attenuated $\beta$-amyloid $(\mathrm{A} \beta)$-induced neurotoxicity in cortical neurons and also prevented increased production of reactive species and loss of mitochondrial membrane potential $\left(\Delta \psi_{m}\right)$ in them. To determine whether the mitochondrial protection conferred by Mito $Q$ was sufficient to prevent the emergence of AD-like neuropathology in vivo, we treated young female 3xTg-AD mice with MitoQ for 5 months and analyzed the effect on the progression of $\mathrm{AD}$-like pathologies. Our results show that $\mathrm{Mito} Q$ prevented cognitive decline in these mice as well as oxidative stress, $\mathrm{A} \beta$ accumulation, astrogliosis, synaptic loss, and caspase activation in their brains. The work presented herein suggests a central role for mitochondria in neurodegeneration and provides evidence supporting the use of mitochondria-targeted therapeutics in diseases involving oxidative stress and metabolic failure, namely AD.

\section{Introduction}

Alzheimer's disease (AD) is the most prevalent of the neurodegenerative diseases and the leading cause of dementia among the elderly. Current therapies are palliative and do not delay the progression of this devastating illness. Extensive evidence indicates that alterations in glucose metabolism and mitochondrial energetics occur along with the accumulation of oxidative damage before the cardinal signs of $\mathrm{AD}$ pathogenesis in the brains of transgenic animal models and patients (Hoyer, 1996; Hirai et al., 2001; Rinaldi et al., 2003; Butterfield et al., 2006; Lin and Beal, 2006; Sultana et al., 2006a,b; Mosconi et al., 2008a; Yao et al., 2009). Such findings have inspired clinical trials of various antioxidant compounds for treating AD. To date, none of the tested compounds have proven effective (Sano et al., 1997; Petersen et al., 2005; Pham and Plakogiannis, 2005; DeKosky et al., 2008). One possible explanation for these failures is that the compounds tested were not efficient at detoxifying relevant reactive species (RS), perhaps because they did not achieve sufficient con-

\footnotetext{
Received Feb. 1, 2011; revised Aug. 12, 2011; accepted Sept. 4, 2011.

Author contributions: M.J.M. and J.L.F. designed research;M.J.M. and J.L.F. performed research; M.P.M. contributed unpublished reagents/analytic tools; M.J.M. and J.L.F. analyzed data; M.J.M. and J.L.F. wrote the paper.

Dr. Murphy has a financial interest in MitoQ.

This work was partially supported by National Institutes of Health Grant NS37110. We thank Rebecca A. Kirkland for critical review of this manuscript.

Correspondence should be addressed to James L. Franklin, Department of Pharmaceutical and Biomedical Sciences, The University of Georgia College of Pharmacy, 357 Wilson Pharmacy, Athens, GA 30602. E-mail: frankli@rx.uga.edu.

DOI:10.1523/JNEUROSCI.0552-11.2011

Copyright $\odot 2011$ the authors $\quad 0270-6474 / 11 / 3115703-13 \$ 15.00 / 0$
}

centrations at the site of most RS production, mitochondria. This potential problem may be overcome by antioxidants that readily traverse the blood-brain barrier and selectively concentrate in mitochondria (Shigenaga et al., 1994; Halliwell and Gutteridge, 2007). The recently developed, mitochondria-targeted antioxidant MitoQ (mitoquinone mesylate: [10-(4,5-dimethoxy-2-methyl-3,6dioxo-1,4-cycloheexadienl-yl) decyl triphenylphosphonium methanesulfonate]) possesses these qualities (James et al., 2005, 2007; Murphy and Smith, 2007).

MitoQ is produced by covalently binding ubiquinone, an endogenous antioxidant and component of the mitochondrial electron transport chain to a triphenylphosphonium $\left(\mathrm{TPP}^{+}\right)$ cation. MitoQ rapidly crosses the blood-brain barrier and neuronal membranes and concentrates several hundred-fold in mitochondria driven by the high membrane potential across the inner mitochondrial membrane (IMM; Murphy and Smith, 2007). The ubiquinone moiety is delivered to the matrix side of the IMM, placing it at the site of most cellular RS generation (Halliwell and Gutteridge, 2007). The TPP ${ }^{+}$moiety adsorbs to the matrix side of the IMM, and the ubiquinone penetrates into the membrane in which it is reduced to the active antioxidant ubiquinol by respiratory complex II. The ubiquinol acts as an antioxidant when oxidized to ubiquinone by RS. Complex II then reduces the ubiquinone to ubiquinol. MitoQ is a poor substrate for complex I and is negligibly oxidized by complex III. Therefore, it cannot substitute for endogenous ubiquinone in the electron transport chain but primarily acts as an antioxidant capable of continuous regen- 
eration by complex II (James et al., 2005, 2007; RodriguezCuenca et al., 2010).

To evaluate the therapeutic potential of MitoQ for treating $\mathrm{AD}$ and to examine a role for mitochondria-generated $\mathrm{RS}$ in $\mathrm{AD}$ progression, we investigated the effect of MitoQ on $\beta$-amyloid $(\mathrm{A} \beta)$ toxicity in primary cultures of mouse cortical neurons and on cognitive deficits and neuropathology in a young triple transgenic $(3 \times \mathrm{Tg}-\mathrm{AD})$ mouse model of $\mathrm{AD}$. We found that MitoQ treatment prevented $\mathrm{A} \beta$-induced oxidative stress and death of cortical neurons in culture and the early cognitive decline, oxidative stress, $\mathrm{A} \beta$ accumulation, synaptic loss, astrogliosis, and caspase activation in the brains of $3 \times \mathrm{Tg}-\mathrm{AD}$ mice.

\section{Materials and Methods}

Reagents. All MitoQ used in these studies was synthesized as described previously (Kelso et al., 2001). MitoQ is deliquescent, making pure MitoQ difficult to work with. For this reason, it was adsorbed to cyclodextrin in a 1:2 complex for the animal feeding experiments. Cyclodextrin is widely used in drug delivery and is not thought to have any significant effects. For the in vitro experiments, pure MitoQ without cyclodextrin was used. The control compound, decyl triphenylphosphonium bromide (dTPP), was purchased from Santa Cruz Biotechnology and was not complexed to $\beta$-cyclodextrin because it is a powder that is readily soluble and not deliquescent. 5-(and -6)-Chloromethyl-2', 7'-dicholorodihydrofluorescein diacetate $\left(\mathrm{CM}-\mathrm{H}_{2} \mathrm{DCFDA}\right)$ and tetramethyl rhodamine methyl ester $\left(\mathrm{TMRM}^{+}\right)$were purchased from Invitrogen. $\mathrm{A} \beta_{(22-35)}$ and $\mathrm{A} \beta_{(1-40)}$ peptides were purchased from Bachem. All other reagents were purchased from Sigma unless otherwise noted.

Mice. The 3xTg-AD mouse model used in this study expresses three mutant human genes: amyloid precursor protein, $\mathrm{APP}_{\text {swe }}$; presenilin-1, $\mathrm{PS}_{\mathrm{M} 146 \mathrm{~V}}$; and four-repeat tau, $\operatorname{tau}_{\mathrm{P} 301 \mathrm{~L}}$ (Oddo et al., 2003b). The first two are associated with early-onset forms of human $\mathrm{AD}$ and the latter with human frontotemporal dementia. These mice and nontransgenic (nonTg) mice from the same 129/C57BL/6 hybrid background strain were kindly provided by Dr. Frank LaFerla (University of California, Irvine, Irvine, CA). Cognitive impairment in $3 \mathrm{xTg}-\mathrm{AD}$ mice emerges as a long-term retention deficit at 4-6 months of age and further develops in an age-dependent manner. There is a transient sex divergence in $3 \mathrm{xTg}-\mathrm{AD}$ pathology, such that young- to middle-aged (6-12 month) female 3xTg-AD mice exhibit enhanced cognitive deficits compared with age-matched male 3xTg-AD (Clinton et al., 2007). Furthermore, mitochondrial function and oxidative stress have been fully characterized only in female 3xTg-AD mice (Yao et al., 2009). The purpose of this study was to determine whether mitochondria-targeted therapeutics could prevent the onset of the behavioral and neuropathological hallmarks of $\mathrm{AD}$ in these mice. Therefore, we chose to study only female transgenic and wild-type mice to minimize variability (attributable to sex differences) and the number of mice necessary to achieve meaningful results.

The mice were group housed and kept on a $12 \mathrm{~h}$ light/dark schedule. All mice were given ad libitum access to food and water. Starting at 2 months of age, female $3 \mathrm{xTg}-\mathrm{AD}$ or female nonTg mice were given MitoQ $(100 \mu \mathrm{M})$ or the negative control for MitoQ (dTPP; $100 \mu \mathrm{M})$ continuously in their drinking water for 5 months. Other age-matched female $3 \mathrm{xTg}-\mathrm{AD}$ and female nonTg mice received water without MitoQ or dTPP. When administered to wild-type mice for several months, MitoQ has no effect on the function of subsequently isolated mitochondria, on mtDNA, on nuclear or mitochondrial gene expression, on whole-body metabolism, on whole-body motor function, or on food and liquid consumption (Rodriguez-Cuenca et al., 2010). Each mouse was handled every day for at least 1 week before behavioral testing and given a general health evaluation. A total of 117 mice were used in these experiments. All animal procedures were in accordance with the National Institutes of Health Guide for the Care and Use of Laboratory Animals.

Cell culture. Cortical neurons were isolated from the cerebral cortex of neonatal C57BL/6 or 129/C57BL/6 mice. After removal of the meninges, the cortices were digested in $2 \mathrm{mg} / \mathrm{ml}$ trypsin in $\mathrm{Ca}^{2+} / \mathrm{Mg}^{2+}$-free HBSS for $20 \mathrm{~min}$ at $35^{\circ} \mathrm{C}$. The solution was diluted with an equal volume of cold HBSS containing $50 \mu \mathrm{g} / \mathrm{ml}$ DNase and centrifuged at $200 \times g$ for $5 \mathrm{~min}$ at $4^{\circ} \mathrm{C}$. The supernatant was removed, and the tissue was washed two times with cold HBSS. The cortical tissue was then dissociated by trituration in growth media (Neurobasal-A medium containing 2\% B27 supplement, $1 \%$ penicillin/streptomycin, $0.1 \%$ L-glutamine) and distributed to polyL-lysine-coated \# 1 glass coverslips or 24-well plastic Costar tissue culture plates (Corning). The cells were seeded in $100 \mu$ l of growth media for a minimum of $2 \mathrm{~h}$ in a $5 \% \mathrm{CO}_{2}$ atmosphere $\left(35^{\circ} \mathrm{C}\right)$ in a humidified cell culture incubator. The media were then aspirated and replaced. Coverslips were maintained in growth medium in $35 \mathrm{~mm}$ plastic cell culture dishes (Costar). Plating density was $3.5 \times 10^{5}$ cells $/ \mathrm{ml}$ media. Media was replaced at 3-4 d in vitro, and experimental treatments began on day 7 . Cortical neuron survival was determined by blinded counting of phasebright/morphologically intact cells in 10 randomly selected fields of view per treatment and was normalized to the average percentage survival of nontreated, sibling cultures.

Microscopy. Microscopy experiments were conducted with a laser scanning confocal microscope (Nikon C1; Southern Micro Instruments) attached to a Nikon Eclipse TE300 inverted microscope. Cells were observed with a $60 \times$ plan oil-immersion objective (NA 1.4) and scanned at $512 \times 512$ or $2048 \times 2048$ pixel resolution. The confocal microscope was controlled by a Dell computer running EZC1 software (Nikon). Confocal pinhole and gain were maintained at constant levels during each experiment. Laser power was $10 \%$ of maximum. Phase-contrast images were taken by a cooled Princeton Micro-Max CCD camera (Princeton Instruments) mounted on the Nikon TE-300 microscope and controlled by MetaMorph software (Molecular Devices).

RS were detected using the redox-sensitive dye $\mathrm{CM}-\mathrm{H}_{2} \mathrm{DCFDA}$. This dye is membrane permeant and is trapped in cells by binding of the chloromethyl group to cellular thiols, primarily in the cytosol. The reduced form of CM- $\mathrm{H}_{2}$ DCFDA becomes intensely fluorescent during oxidation by multiple RS, thus providing an assay of generalized RS production (Royall and Ischiropoulos, 1993; Halliwell and Gutteridge, 2007). CM- $\mathrm{H}_{2}$ DCFDA is relatively insensitive to oxidation by superoxide $\left(\mathrm{O}_{2}^{--}\right)$produced by mitochondria or other sources. However, it is easily oxidized by RS that lie downstream of dismutation of $\mathrm{O}_{2}^{-}$, including hydroxyl radicals $\left(\mathrm{OH}^{-}\right)$, peroxynitrite $\left(\mathrm{ONOO}^{-}\right)$, and a number of other radical and nonradical RS. We extensively characterized the use of this dye in rat and mouse neurons (Kirkland and Franklin, 2001; Kirkland et al., 2002). This characterization shows that CM- $\mathrm{H}_{2}$ DCFDA is trapped in neurons, is insensitive to $\mathrm{pH}$ changes within the physiological range, and is not photo-oxidized by the laser power and exposure time used in these experiments. Cultures were incubated in the appropriate experimental medium containing CM- $\mathrm{H}_{2}$ DCFDA $(10 \mu \mathrm{M})$ for $10 \mathrm{~min}$ at $35^{\circ} \mathrm{C}$. They were then washed twice with Leibovitz's L-15 medium and left in the last wash for confocal microscopy. CM- $\mathrm{H}_{2}$ DCFDA was excited with the $488 \mathrm{~nm}$ line of the confocal laser. The green photomultiplier channel of the microscope was used for image acquisition.

The cationic fluorescent probe $\mathrm{TMRM}^{+}$accumulates in mitochondria because of the high membrane potential across the IMM and, therefore, provides a semiquantitative estimate of $\Delta \psi_{m}$. Neurons were incubated with low concentrations $(20 \mathrm{nM})$ of $\mathrm{TMRM}^{+}$in experimental medium for 30 min, rinsed once with L-15, and viewed in L-15 containing $20 \mathrm{nM} \mathrm{TMRM}^{+}$. At equilibrium, the fluorescence produced by this low concentration of $\mathrm{TMRM}^{+}$(excitation 543/emission red photomultiplier channel) is a direct function of $\Delta \psi_{m}$, and complications attributable to self-quenching of the dye are eliminated (Nicholls and Budd, 2000; Nicholls and Ward, 2000; Nicholls and Ferguson, 2002).

Dye intensities in images were quantified by measuring the raw pixel intensities in neuronal somas with the region tool of MetaMorph software. The area quantified covered $60 \mu \mathrm{m}^{2}$ of the somas. The dye intensity measured in each neuron was normalized to the average dye intensity of control nonTg neurons receiving the same concentration of dye for the same period as the experimental cells. Normalized data are shown as fold change from the average intensity of the dye measured in control cultures (untreated cultures of nonTg cortical neurons plated at the same time).

Spatial learning and memory retention. After 4.5 months of experimental treatments, spatial learning and memory retention were determined by the Morris water maze (MWM; Morris, 1984) behavioral test. The apparatus used for the MWM tasks consisted of a circular aluminum tank 
(4 feet diameter) painted white and filled with water maintained at $24 \pm$ $1^{\circ} \mathrm{C}$. Nontoxic, white tempura paint was used to conceal a slightly submerged, circular Plexiglas platform (14 cm diameter). MWM tests were conducted according to Billings et al. (2005) with minor modifications. Mice were placed on the platform for $10 \mathrm{~s}$ before the first training trial to reduce stress and associate them with the presence of the escape platform. During the acquisition trails, the mice were placed in the tank at one of four designated start points and allowed $60 \mathrm{~s}$ to find and escape onto the platform using at least three distinct, extra-maze cues on the curtains surrounding the tank. If a mouse failed to find the platform within the allotted time, it was manually guided there, and the escape latency was recorded as $60 \mathrm{~s}$. In either case, the mouse remained on the platform for 30 s to consolidate the spatial cues (Buccafusco, 2001; Arendash et al., 2006). After this time, the mouse was allowed to rest in a holding cage fitted with a warm towel for $30 \mathrm{~s}$ until the start of the next trial. Each mouse was given four consecutive trials per day for $7 \mathrm{~d}$ (Vorhees and Williams, 2006). Short- and long-term retention of the spatial training was assessed in probe trials (platform removed) conducted 1.5 and $24 \mathrm{~h}$, respectively, after the last acquisition trial. Spatial bias for the platform location was determined by the number of crosses over the previous platform location during a $60 \mathrm{~s}$ free swim.

Cued acquisition trials were conducted after the last probe trial to determine whether differences in learning and memory could be attributed to impaired eyesight, swimming ability, or motivation to escape (Morris, 1984). In the cued trials, extra-maze cues were removed, and the platform was made visible by a mounted flag. Multiple parameters in all MWM tasks were calculated and analyzed by Ethovision XT tracking software (Noldus Information Technology).

Tissue acquisition. At 7 months of age, mice were killed by cervical dislocation and intracardially perfused with PBS, pH 7.4. Brains were rapidly removed and sagittally split. One hemi-brain was fixed in $4 \%$ paraformaldehyde for immunohistochemistry. After removal of the brainstem and cerebellum, the other hemi-brain was snap frozen in liquid nitrogen and stored at $-80^{\circ} \mathrm{C}$ for use in biochemical analysis.

Immunohistochemistry. Hemi-brains were fixed for $48 \mathrm{~h}$ in $4 \%$ paraformaldehyde, embedded in paraffin, cut into $5 \mu \mathrm{m}$ sections, and mounted on glass slides. Sections were deparaffinized, rehydrated, and heated in $10 \mathrm{~mm}$ sodium citrate, $\mathrm{pH} 6.0$, to $\sim 95^{\circ} \mathrm{C}$ to assist in antigen retrieval. The sections were incubated in blocking buffer $(150 \mathrm{~mm} \mathrm{NaCl}$, $100 \mathrm{~mm}$ Tris $\mathrm{pH} 7.4,0.1 \%$ Triton $\mathrm{X}-100,2 \% \mathrm{BSA}$ ) for $1 \mathrm{~h}$ at room temperature, followed by anti-A $\beta_{(1-42)}$ antibody (1:500; BioSource International) overnight at $4^{\circ} \mathrm{C}$ (Oddo et al., 2003b). A $\beta_{(1-42)}$ was visualized by using an $\mathrm{ABC}$ immunoperoxidase kit from Vector Laboratories and diaminobenzidine substrate. Images were taken by a CCD camera mounted on a Nikon TE-300 microscope. Image acquisition was controlled by MetaMorph software.

Immunoblotting. Previously frozen hemi-brains were homogenized in $2 \%$ SDS lysis buffer (50 mm Tris, 2 mm EDTA, $150 \mathrm{~mm} \mathrm{NaCl}$ ) supplemented with $100 \times$ protease inhibitor cocktail (Sigma) and centrifuged at $4^{\circ} \mathrm{C}$ for $1 \mathrm{~h}$ at $100,000 \times \mathrm{g}$ in an ultracentrifuge. Protein concentration of the supernatant was determined by the Bradford assay (Pierce). Equal amounts of protein from each sample were separated by SDS-PAGE and transferred to equilibrated PVDF membranes (Millipore). Membranes were blocked for at least $1 \mathrm{~h}$ at room temperature with TBST $(10 \mathrm{~mm}$ Tris- $\mathrm{HCl}, 100 \mathrm{~mm} \mathrm{NaCl}$, and $0.1 \%$ Tween-20) containing 5\% nonfat dry milk, followed by incubation in primary anti- $\Delta$ tau ( $1 \mu \mathrm{g} / \mathrm{ml}$; Invitrogen), anti-3-nitrotyrosine (3-NT) (1 $\mu \mathrm{g} / \mathrm{ml}$; Cayman Chemical), antisynaptophysin (1:200 dilution; Sigma), or anti-glial fibrillary acidic protein (GFAP; $2.5 \mu \mathrm{g} / \mathrm{ml}$; Sigma) diluted in $1 \%$ nonfat dry milk overnight at $4^{\circ} \mathrm{C}$. The membranes were then washed for $20 \mathrm{~min}$ in TBST and then incubated for $1 \mathrm{~h}$ at room temperature in anti-mouse HRP-linked secondary antibody (1:2000; Bethyl Laboratories), followed by another 20 min wash. The membranes were stripped with Restore Stripping Buffer (Pierce), washed in TBST, and processed as described above for $\beta$-actin or $\beta$-tubulin (Sigma) as a loading control. Proteins were detected using the chemiluminescent SuperSignal substrate (Pierce).

Amyloid $_{(1-42)}$ ELISA. Soluble A $\beta_{(1-42)}$ was extracted as described by Oddo et al. (2003b), with modifications necessary for the ELISA kit (Covance). Previously frozen hemi-brains were Dounce homogenized in the appropriate amount ( $150 \mathrm{mg} / \mathrm{ml}$ wet weight) of ice-cold $0.6 \%$ SDS lysis buffer ( $50 \mathrm{~mm}$ Tris, $2 \mathrm{~mm}$ EDTA, $150 \mathrm{~mm} \mathrm{NaCl}$ ), supplemented with $100 \times$ protease inhibitor cocktail (Sigma). The resulting homogenate was sonicated and centrifuged at $4^{\circ} \mathrm{C}$ for $1 \mathrm{~h}$ at $100,000 \times g$ in a Beckman Coulter Optima TLX-120 ultracentrifuge. The supernatant containing the soluble protein fraction was collected and further analyzed according to the ELISA kit instructions. Briefly, $100 \mu \mathrm{l}$ of the samples or $\mathrm{A} \beta_{(1-42)}$ peptide standards were added to each well in duplicate or triplicate and incubated overnight at $4^{\circ} \mathrm{C}$. The following day, the 96 -well plate was thoroughly washed, incubated in tetramethylbenzidine substrate for 40 $\mathrm{min}$ at room temperature, and the absorbance at $620 \mathrm{~nm}$ was recorded by a SpectraMax M2 microplate reader. Quantification of soluble $\mathrm{A} \beta_{(1-42)}$ levels in the samples was achieved by normalizing the $\mathrm{A} \beta_{(1-42)}$ concentration detected to the total protein in each sample, as determined by the Bradford protein assay (Pierce).

Lipid peroxidation. Lipid peroxidation was assessed by measuring thiobarbituric acid reactive substances (TBARS). Brain homogenates (0.02 $\mathrm{g} / \mathrm{ml} 50 \mathrm{~mm}$ Tris- $\mathrm{HCl}$ ) were diluted in 2 vol of $15 \%$ trichloroacetic acid and centrifuged at $1000 \times g$ for $10 \mathrm{~min}$ at $4^{\circ} \mathrm{C}$. The supernatant was added to an equal volume of $0.375 \% \mathrm{TBA}$ in $0.25 \mathrm{M} \mathrm{HCl}$ and heated at $100^{\circ} \mathrm{C}$ for $15 \mathrm{~min}$. To prevent additional peroxidation of lipids during the assay, $0.015 \% 2$, 6-di-tert-butyl-4-methylphenol was added to the mixture before the acid-heating stage. After cooling and centrifugation at $100 \times g$ for $5 \mathrm{~min}$, the formation of TBARS was determined by the absorbance of the colorimetric product at $532 \mathrm{~nm}$ by a SpectraMax M2 microplate reader (Molecular Devices). The amount of TBARS in the samples was calculated from a standard curve produced by hydrolysis of tetraethoxypropane. Results were normalized to protein concentration of each sample.

Glutathione assay. The ratio of reduced glutathione (GSH) to oxidized glutathione (GSSG) was determined by a luminescent assay (Promega). Brains were Dounce homogenized $(0.01 \mathrm{mg} / \mathrm{ml})$ in PBS containing $2 \mathrm{~mm}$ EDTA and briefly centrifuged, and the supernatant was collected. The GSH standards and samples were diluted accordingly in lysis buffer containing luciferin substrate. $N$-ethylmaleimide was included in aliquots of some samples to block GSH and allow quantification of GSSG. The samples were then incubated in buffer containing glutathione $S$-transferase for $30 \mathrm{~min}$ at room temperature. The reaction was stopped with addition of the detection reagent and incubated for $15 \mathrm{~min}$, and the luminescence was quantified by a SpectraMax M2 microplate reader. The linear portion of the glutathione standard curve $(0-8 \mu \mathrm{M})$ was used to calculate the ratio of GSH/GSSG in the samples.

Caspase 3/7 activity assay. Caspase 3/7 activity was measured using the Caspase-Glo 3/7 kit (Promega) according to the instructions of the manufacturer with modifications for tissue homogenates (Liu et al., 2004). Briefly, brain extracts were prepared by Dounce homogenization in icecold hypotonic extraction buffer (25 mM HEPES, pH 7.5, $5 \mathrm{~mm} \mathrm{MgCl}_{2}, 1$ mM EGTA) and centrifuged for $15 \mathrm{~min}$ at 13,000 rpm. Protein concentrations of the supernatant were determined using the Bradford assay (Pierce) to ensure equal loading. Samples were diluted accordingly in PBS and loaded in duplicate or triplicate into a white-walled, 96-well plate for $1 \mathrm{~h}$ incubation in an equal volume of Caspase-Glo reagent at room temperature. The luminescence of each sample, a measure of caspase 3/7 activity, was measured by a SpectraMax M2 microplate reader and normalized to the respective nonTg control. This assay does not distinguish between the activities of caspases 3 and 7 .

Statistics. Statistical analysis and graph preparation were done with SigmaPlot 11.1 (Systat Software). Statistical comparisons were made by Kruskal-Wallis one-way ANOVA on ranks, followed by all pairwise multiple comparisons post hoc tests. Error bars are \pm SEM.

\section{Results \\ MitoQ attenuated $\mathrm{A} \beta$ toxicity in cortical neurons in cell culture}

Manczak et al. (2010) recently demonstrated that MitoQ protects mitochondria from $A \beta$-induced toxicity in N2a cells. They also demonstrated that MitoQ enhances neurite outgrowth in cultured hippocampal neurons from $\mathrm{A} \beta \mathrm{PP}$-expressing mice but did 
not present direct evidence of a protective effect of MitoQ on the mitochondria in these cells. To determine whether MitoQ can prevent $\mathrm{A} \beta$ toxicity in primary neurons and to explore its effect on mitochondria, we investigated its effects on mouse cortical neurons treated with $\mathrm{A} \beta_{(22-35)}$ in cell culture. This $\mathrm{A} \beta$ peptide fragment contains the biologically active portion of $\mathrm{A} \beta$ (Yanker et al., 1990; Takadera et al., 1993). It has the experimental advantage for in vitro studies of rapidly aggregating in aqueous solutions (Pike et al., 1993). A $\beta_{(22-35)}$ forms amyloid fibrils in vitro resembling those of the $\beta$-amyloid protein in senile plaques and exhibits a toxicity profile that parallels that of full-length $\mathrm{A} \beta_{(1-40)}$ and $\mathrm{A} \beta_{(1-42)}$ in hippocampal and cortical neurons in cell culture (Pike et al., 1995; Casley et al., 2002b). An even shorter peptide $\left[\mathrm{A} \beta_{(25-35)}\right]$ causes memory impairment when injected into rat brains (Díaz et al., 2010).

$\mathrm{A} \beta_{(22-35)}$ treatment caused a progressive reduction in cortical neuron survival that declined by $48 \mathrm{~h}$ to $\sim 35 \%$ that of untreated controls (Fig. 1A,B). Low concentrations of MitoQ (1-100 nM) greatly inhibited this toxicity. dTPP, a compound that is structurally identical to MitoQ but that lacks the ubiquinone moiety, was used to control for nonspecific effects of the lipophilic cation. dTPP did not increase survival of $A \beta_{(22-35)}$-treated neurons. Figure $1 C$ shows that, similar to its effect on $\mathrm{A} \beta_{(22-35)}, 1 \mathrm{~nm}$ MitoQ also prevented death of cortical neurons treated with full-length $\mathrm{A} \beta_{(1-40)}$. In other studies, the $\mathrm{EC}_{50}$ for MitoQ in cultured cells was $<0.5 \mathrm{nM}$, and the protective effect then plateaued over several logs of concentration (Jauslin et al., 2003). Therefore, our findings in neuronal cells are consistent with other studies.

\section{MitoQ attenuated $\mathrm{A} \beta$-induced $\mathrm{RS}$ and mitochondrial damage in cortical neurons in cell culture}

$\mathrm{A} \beta$, and its precursor APP, localize, in part, to mitochondria in which they can cause mitochondrial dysfunction as evidenced by increased production of RS, enzyme inhibition, loss of cytochrome $c$, and depolarization of $\Delta \psi_{m}$ (Casley et al., 2002a; Kim et al., 2002; Anandatheerthavarada et al., 2003; Jang and Surh, 2003; Lustbader et al., 2004; Liang et al., 2009; Takuma et al., 2009). To evaluate the effect of MitoQ on A $\beta$-induced RS and mitochondrial damage, cortical neurons in cell culture were treated with $\mathrm{A} \beta_{(22-35)}$ for $24 \mathrm{~h}$ in the presence or absence of MitoQ. A similar amyloid fragment has been reported to impair mitochondrial function in isolated brain mitochondria (Canevari et al., 1999). Confocal microscopy allowed simultaneous assessment in single cells of changes in RS by the redox-sensitive dye CM- $\mathrm{H}_{2}$ DCFDA and $\Delta \psi_{m}$ by the potential-dependent fluorescent dye TMRM $^{+}$ (Fig. $2 A$ ). A $\beta_{(22-35)}$ treatment for $24 \mathrm{~h}$ induced a $3.4 \pm 0.2$-fold average increase in $\mathrm{CM}-\mathrm{H}_{2}$ DCFDA intensity, indicating elevated neuronal RS production. This treatment also significantly depolarized $\Delta \psi_{m}(p<0.01)$, suggesting damage to the IMM. MitoQ ( 1 and $5 \mathrm{nM}$ ) prevented the increased RS caused by $\mathrm{A} \beta_{(22-35)}$ treatment and maintained $\Delta \psi_{m}$ at levels indistinguishable from controls (Fig. $2 B, C$ ). A $\beta_{(22-35)}+$ dTPP-treated neurons had RS and $\Delta \psi_{m}$ levels that were not significantly different from those of cells treated with $\mathrm{A} \beta_{(22-35)}$ alone, indicating the antioxidant moiety of MitoQ was responsible for its protective effects.

$\mathrm{A} \beta$ induces production of $\mathrm{O}_{2}^{--}$, nitric oxide ( $\mathrm{NO}^{\circ}$ ), and multiple RS downstream of these radicals in many cells, including cortical neurons (Keller et al., 1998; Longo et al., 2000; Keil et al., 2004; Malinski, 2007; Stepanichev et al., 2008; Díaz et al., 2010). The $\mathrm{A} \beta_{(22-35)}$-induced increases in $\mathrm{O}_{2}^{--}$and $\mathrm{NO}^{*}$ leads to formation of $\mathrm{ONOO}^{-}$attributable to the diffusion-controlled reaction between $\mathrm{O}_{2}^{--}$and $\mathrm{NO}^{\circ}$ (Beckman and Koppenol, 1996). Given the sensitivity of $\mathrm{CM}-\mathrm{H}_{2} \mathrm{DCFDA}$ to oxidation by $\mathrm{ONOO}^{-}$, in com-
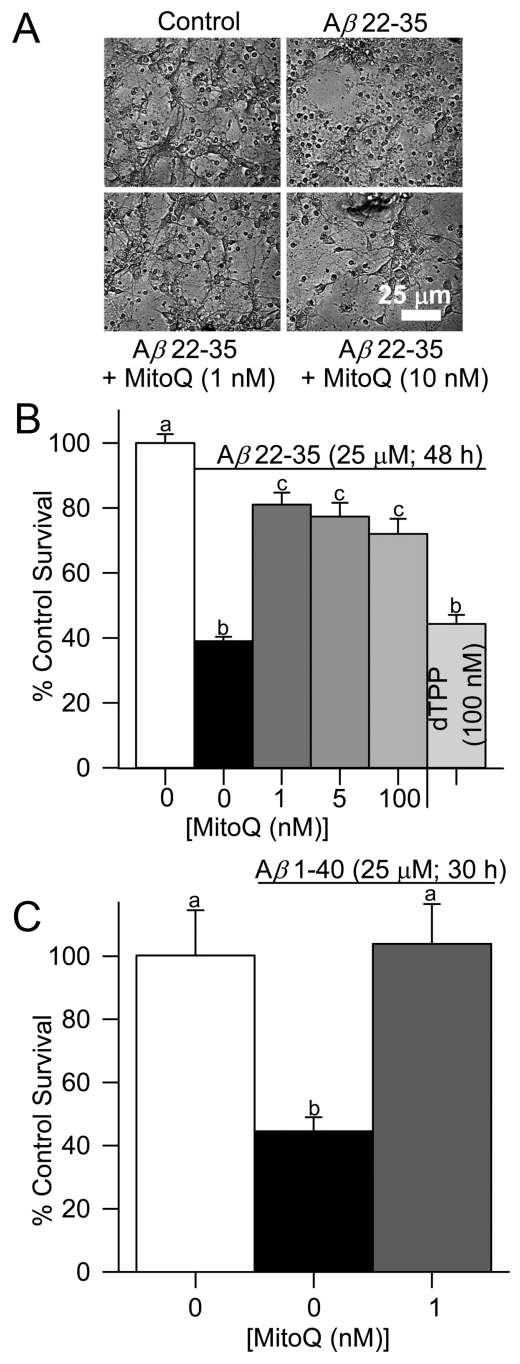

Figure 1. Mito $Q$ inhibited $A \beta$-induced death of $C 57 \mathrm{BL} / 6$ mouse cortical neurons in cell culture. $A$, Photomicrographs of untreated cortical neurons and cortical neurons exposed to $\mathrm{A} \beta_{(22-35)}(25 \mu \mathrm{m})$ alone or with Mito $\mathrm{Q}$ for $48 \mathrm{~h}$. This concentration was chosen because similar concentrations of truncated or full-length $A \beta$ peptides are reported to be toxic to cells in culture (Mazziotti and Perlmutter, 1998). B, MitoQ prevented most cell death caused by $A \beta_{(22-35)} . n=$ 30 cultures per condition except for $100 \mathrm{~nm}$ Mito $\mathrm{Q}$ or dTPP in which $n=9$ cultures per condition. C, Mito $Q$ also prevented $A \beta_{(1-40)}$-induced death. $n=9$ cultures per condition. After treatments, neurons were fixed, counted, and quantified as percentage of the average number of healthy (phase-bright) neurons in control, sibling cultures. Identical letters in this and subsequent figures indicate conditions that are not statistically different $(p>0.01)$. Different letters in this and subsequent figures signify that the conditions are significantly different from conditions with other letters $(p<0.01)$.

bination with the propensity of $\mathrm{ONOO}^{-}$formation attributable to $\mathrm{A} \beta$-induced stress, we reasoned that the primary RS detected in our paradigm was $\mathrm{ONOO}^{-}$(Setsukinai et al., 2003; Malinski, 2007). Treatment of $A \beta_{(22-35)}$-exposed cultures with the nitric oxide synthase (NOS) inhibitor $N^{\mathrm{G}}$-nitro-L-arginine methyl ester (L-NNA) decreased CM- $\mathrm{H}_{2}$ DCFDA fluorescence intensity to that found in control cultures, confirming that the RS responsible for $\mathrm{CM}-\mathrm{H}_{2}$ DCFDA oxidation were primarily nitrogen-associated species $(p<0.001 \mathrm{~A} \beta$ vs $\mathrm{A} \beta+$ L-NNA).

$\mathrm{A} \beta$ is reported to increase RS in neurons via multiple mechanisms, including direct $\mathrm{A} \beta$-induced $\mathrm{RS}$ production, elevated NADPH oxidase activity, interaction with mitochondria-associated $\mathrm{A} \beta$ alcohol dehydrogenase, inhibition of cytochrome oxidase (respiratory complex IV), and by causing leakage of electrons from 
A
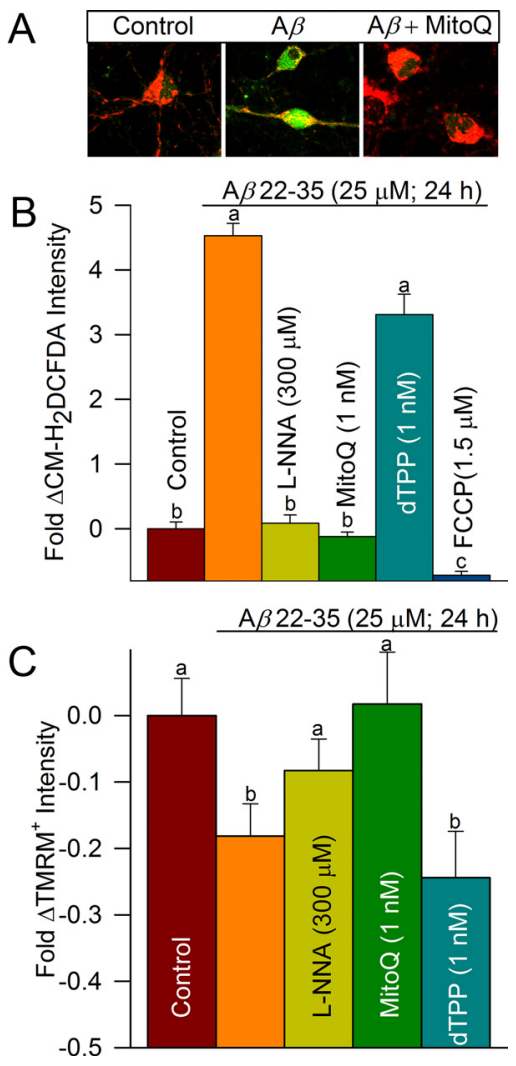

Figure 2. Mito $Q$ prevented increased $A \beta$-induced RS production and $A \beta$-induced $\Delta \psi_{m}$

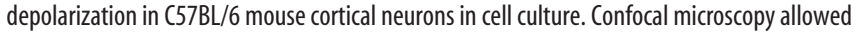
simultaneous assessment of RS by the redox-sensitive dye CM- $\mathrm{H}_{2}$ DCFDA and $\Delta \psi_{m}$ by the potential-dependent fluorescent dye TMRM ${ }^{+}$. $A$, Confocal micrographs of mouse cortical neurons costained with $\mathrm{CM}_{2} \mathrm{H}_{2} \mathrm{DCFDA}$ (green) and $\mathrm{TMRM}^{+}$(red). RS levels, indicated by increased CM- $\mathrm{H}_{2}$ DCFDA intensity, were much higher in cells treated for $24 \mathrm{~h}$ with $\mathrm{A} \beta_{(22-35)}(25 \mu \mathrm{m})$ peptide. Mito $Q$ (1 nM) blocked the increased RS caused by exposure of neurons to $A \beta_{(22-35)}$. $B$, Mito $Q$ and the NOS inhibitor L-NNA suppressed increased RS caused by $A \beta_{(22-35)}$ exposure. dTPP, which mimics the mitochondria targeting moiety of Mito $Q$ but contains no ubiquinone, had no significant effect. The uncoupling agent FCCP blocked RS at a concentration that eliminates $\Delta \psi_{m}$ in neurons (Kirkland et al., 2010). C, MitoQ and L-NNA also blocked depolarization of $\Delta \psi_{m}$ (decreased TMRM ${ }^{+}$intensity) caused by A $\beta_{(22-35)}$ peptide, whereas dTPP had no effect. Dye intensity was determined in confocal micrographs with MetaMorph software and normalized to the average dye intensity of control cultures plated at the same time. Dye intensities are shown as fold change from these values.

the mitochondrial electron transport chain (Hensley et al., 1994; Canevari et al., 1999; Lustbader et al., 2004; Takuma et al., 2005; Shelat et al., 2008; Rhein et al., 2009; Saraiva et al., 2010). The generation of RS by leakage of electrons from the electron transport chain is highly dependent on maintenance of the electrochemical gradient across the IMM (Turrens, 1997). We used the uncoupling agent carbonyl cyanide $p$-trifluoromethoxyphenylhydrazone (FCCP) to break down this gradient. By decreasing the proton gradient across the IMM, FCCP increases rate of electron transport through the respiratory chain, thereby inhibiting electron leakage and consequently mitochondrial $\mathrm{O}_{2}^{--}$production. Consistent with the findings of others (Saraiva et al., 2010), brief incubation with FCCP caused the loss of most CM- $\mathrm{H}_{2}$ DCFDA fluorescence in $\mathrm{A} \beta_{(22-35)}$-treated cortical neurons (Fig. $2 \mathrm{~B}$ ), suggesting that the RS detected by this dye was primarily of mitochondrial origin (Duchen, 1999). Together, these results suggest that MitoQ decreased $\mathrm{CM}-\mathrm{H}_{2}$ DCFDA oxidation in $\mathrm{A} \beta$-treated cortical neurons primarily by suppressing RS produced by mitochondria. $\Delta \psi_{m}$ not only influences RS generation but other critical mito-
Table 1. Ages in months at which AD-like pathologies first appear in 3xTg-AD mice

\begin{tabular}{lcl}
\hline Condition & Ages & References \\
\hline Mitochondrial dysfunction & 3 & Yao et al., 2009 \\
Oxidative stress & 3 & Resende et al., 2008 \\
Intraneuronal A $\beta$ staining & 4 & Billings et al., 2005 \\
Extracellular A $\beta$ (plaques) & 6 & Billings et al., 2005 \\
Memory deficits & 4 & Billings et al., 2005 \\
Neurofibrillary tangles & 12 & Rissman et al., 2004 \\
Synaptic dysfunction & 6 & Oddo et al., 2003b \\
\hline
\end{tabular}

Mitochondrial dysfunction and oxidative stress are the earliest pathologies noted in the brains of 3xTg-AD mice. The pathologies shown continue to progress as the animals age. $A \beta$ deposition occurs in cortex, hippocampus, and amygdala. Synaptic dysfunction was determined in CA1.

chondrial functions, such as nicotinamide adenine dinucleotide reduction, ATP synthesis, and $\mathrm{Ca}^{+}$sequestration, and is therefore considered the primary dictator of mitochondrial energetics as well as an indicator of the overall health of mitochondria in neurons (Nicholls and Ward, 2000). The ability of MitoQ treatment to maintain $\Delta \psi_{m}$ at control levels suggests that MitoQ preserved the functional integrity of neuronal mitochondria by preventing $\mathrm{A} \beta$-induced $\mathrm{NO} \%$ $\mathrm{O}_{2}^{--} / \mathrm{ONOO}^{-}$damage to critical components of the IMM.

Treating cultures of cortical neurons obtained from the $3 x T g-A D$ mouse model of $\mathrm{AD}$ (Oddo et al., 2003b) with $\mathrm{A} \beta_{(22-35)}$ caused cell death similar to that shown in Figure 1 for wild-type cells (data not shown). Exposure of these cultures to $25 \mu \mathrm{M} \mathrm{A} \beta_{(22-35)}$ for $24 \mathrm{~h}$ increased $\mathrm{CM}-\mathrm{H}_{2}$ DCFDA intensity $3.4 \pm 0.2$-fold $(p<0.01$ compared with untreated control average; $n=34$ neurons). As it did for wild-type cells (Fig. $2 A, B$ ), inclusion of MitoQ $(10 \mathrm{nM})$ in the media during $\mathrm{A} \beta_{(22-35)}$ exposure prevented this increase $(0.3 \pm 0.19$-fold compared with control; $p>0.1 ; n=$ 49). Therefore, the response of the neurons to $A \beta_{(22-35)}$ and to MitoQ was similar to that of wild-type cortical neurons in culture.

There is extensive in vitro evidence that the concentrations of MitoQ used here have no impact on mitochondrial functions, such as ATP production, membrane potential, or ROS production in cells or mitochondria, but do prevent mitochondrial oxidative damage under conditions that lead to oxidative stress (Kelso et al., 2001; Jauslin et al., 2003; Saretzki et al., 2003; AsinCayuelaa et al., 2004).

\section{MitoQ improved cognitive performance in young $3 \times \mathrm{xT}-\mathrm{AD}$ mice}

A number of studies show that, when MitoQ is administered to in vivo animal models of pathologies, it reduces both oxidative damage and the pathologies (Adlam et al., 2005; Lowes et al., 2008; Graham et al., 2009; Supinski et al., 2009; Chacko et al., 2010; Smith and Murphy 2010). The positive results of the MitoQ drug-screening experiments (Figs. 1, 2) suggested that MitoQ might be an effective treatment for $\mathrm{AD}$. To evaluate the therapeutic potential of MitoQ for treating $\mathrm{AD}$ and to examine a possible role for oxidative stress in $\mathrm{AD}$ progression, we investigated the effect of MitoQ on cognitive performance in the 3xTg-AD mouse model of AD. This mouse strain develops cognitive dysfunction as well as both plaque and neurofibrillary tangle pathology in $\mathrm{AD}$-relevant brain regions in an age-dependent manner, closely resembling $\mathrm{AD}$ progression in humans (Oddo et al., 2003b). Notably, the earliest pathological changes in $3 \times \mathrm{Tg}-\mathrm{AD}$ mice involve mitochondrial impairment and increased oxidative stress (Resende et al., 2008; Yao et al., 2009). Table 1 shows the ages at which various cognitive pathologies and neuropathologies are reported to first occur in these mice. Most deficits, other than neurofibrillary tangles (NFTs), occur within the first few months 
of the lives of these animals. Because of the long period of treatment necessary to test the ability of MitoQ to ameliorate NFT formation (up to 18 months), we chose to determine its effects only on the early pathologies.

Spatial retention deficits emerge in $3 \mathrm{xTg}-\mathrm{AD}$ mice by $4-6$ months of age and are reminiscent of spatial learning deficits in patients with mild cognitive impairment (MCI), a condition proposed to be prodromal for AD (Grundman et al., 2004; Mosconi et al., 2008a). The mitochondrial dysfunction evident in these mice also recapitulates multiple parameters found in MCI and early $\mathrm{AD}$ patients, including decreased mitochondrial bioenergetics, increased oxidative stress, and increased mitochondrial A $\beta$ load (Billings et al., 2005; Yao et al., 2009). Consequently, young $3 \mathrm{xTg}-\mathrm{AD}$ mice provide a valuable model for the evaluation of prophylactic therapeutics (Billings et al., 2005). Only female $3 \mathrm{xTg}-\mathrm{AD}$ and wild-type mice were used in this study because they exhibit an earlier and more pronounced AD phenotype than do males (Clinton et al., 2007). To test the effect of MitoQ on cognitive performance, female $3 \mathrm{xTg}$-AD mice were either left untreated or received a continuous supply of $100 \mu \mathrm{M}$ MitoQ or 100 $\mu \mathrm{M}$ dTPP in their drinking water from 2-7 months of age. Agematched nonTg female mice either received no treatment or 100 $\mu \mathrm{M}$ MitoQ in their drinking water from 2-7 months of age. After 4.5 months of treatment, the cognitive performance of these six groups was determined by performance in the MWM (Morris, 1984). All mice were able to learn the MWM task, because the average escape latency for each group gradually decreased to reach a predetermined criterion ( $<25 \mathrm{~s}$ average latency) during $7 \mathrm{~d}$, hidden-platform training trials. Untreated nonTg, nonTg receiving MitoQ treatment, and 3xTg-AD mice receiving MitoQ treatment performed at a similar rate, reaching criterion on day 4 . The untreated $3 \times \mathrm{Tg}-\mathrm{AD}$ and dTPP-treated $3 \mathrm{xTg}-\mathrm{AD}$ mice required additional training to learn the task (Fig. 3A). MitoQ treatment significantly enhanced $3 \times \mathrm{Tg}-\mathrm{AD}$ performance on acquisition trials to a level indistinguishable from nonTg and nonTg receiving MitoQ treatment $(p<0.01)$. Conversely, treatment with the negative control dTPP did not affect the performance of 3xTg-AD mice $(p>0.05$ for $3 x T g-A D+$ dTPP vs $3 \times \mathrm{Tg}-\mathrm{AD}$ on all training days). To determine the effect of MitoQ treatment on short- and long-term spatial memory retention, the platform was removed and spatial bias for the previous platform location in the MWM was analyzed in probe trials conducted 1.5 and $24 \mathrm{~h}$ after the last training trial. MitoQ prevented the longterm retention deficit in $3 \mathrm{xTg}-\mathrm{AD}$ mice (Fig. $3 B$ ). These mice performed at the same level as nonTg controls. An analogous trend was evident in the short-term probe.

The effect of MitoQ on rate of learning in the $3 x T g-A D$ mice could not be explained by a stimulatory effect of MitoQ or by an effect of MitoQ on vision. Cued acquisition trials in which the escape platform was made visible to the mice were conducted after the last probe trial (Fig. 3C). There were no differences in the average times in which mice in each group reached the platform, indicating no visual problems. The average swim speed was $\sim 21$ $\mathrm{cm} / \mathrm{s}$ for each group $(p=0.84)$, indicating that motor performance was the same for all and that the MitoQ did not have a stimulatory effect. Rather, MitoQ enhanced learning and spatial memory retention. Therefore, the $3 x \mathrm{Tg}$ mice receiving MitoQ treatment performed as well as nonTg mice on all tasks, indicating that MitoQ therapy effectively prevented the onset of ADassociated cognitive decline in them. The negative control dTPP produced no effect on acquisition or probe trials, indicating that the cognitive enhancement in MitoQ-treated mice was attributable to the antioxidant moiety.
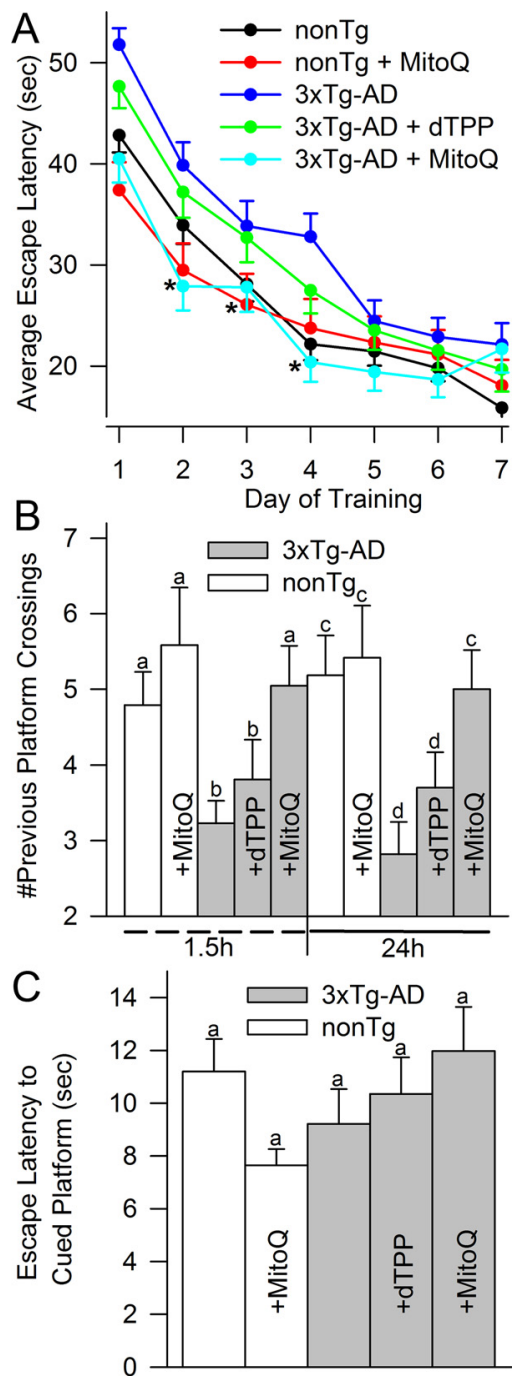

Figure 3. Mito $Q$ treatment prevented the onset of cognitive deficits in young female $3 \times \mathrm{Tg}$-AD mice. $\boldsymbol{A}$, Time courses of spatial learning and memory acquisition in the MWM. At 6.5 months of age, five groups of female mice having the specified genotypes and that had received the indicated treatments for 4.5 months were trained in the MWM (for details, see Materials and Methods). Each mouse performed four training trials per day for 7 consecutive days, and the latencies in seconds for each animal to reach a platform hidden under opaque water per day were averaged. All trials were filmed by digital camera, and the data were analyzed by EthoVision software. All groups were able to perform the task with equal latencies after $7 \mathrm{~d}$ of training. However, the nonTg, nonTg + Mito $Q$, and $3 \times T g-A D+$ Mito 0 mice learned the task more quickly than did untreated or dTPP-treated 3xTg-AD mice $(p<0.01$ by longitudinal regression analysis, indicated by asterisks). Treated mice received either dTPP (100 $\mu \mathrm{M})$ or MitoQ (100 $\mu \mathrm{M})$ in their drinking water from 2 to 7 months after birth. $B$, Mito $Q$ treatment prevented loss of short- and long-term spatial memory retention in the $3 \times \mathrm{Tg}$-AD mice. Memory retention was assessed in MWM probe trials conducted 1.5 and $24 \mathrm{~h}$ after the last training trials. In the probe trials, the platform was removed from the water tank, and mice were allowed a 60 s free swim. Spatial bias is shown as the number of previous platform location crosses as determined by video analysis using Ethovision tracking software. MitoQ significantly prevented both shortand long-term retention deficits in 3xTg-AD mice. Conversely, dTPP treatment did not significantly affect learning or memory in these mice. C, Cued acquisitions trials in which the platform was not hidden revealed that all mice were capable of swimming to the visible platform in the same amount of time ( $p=0.7$ by ANOVA). $n=21-38$ mice except for the MitoQ-exposed nonTg in which 12 animals were treated.

\section{MitoQ decreased oxidative stress, synaptic loss, and astrogliosis in the cortex of 3xTg-AD mice}

Resende et al. (2008) reported that several markers for oxidative stress were higher in the brains of 3- to 5-month-old 3xTg-AD mice than in nonTg mice of the same age. Among these markers 

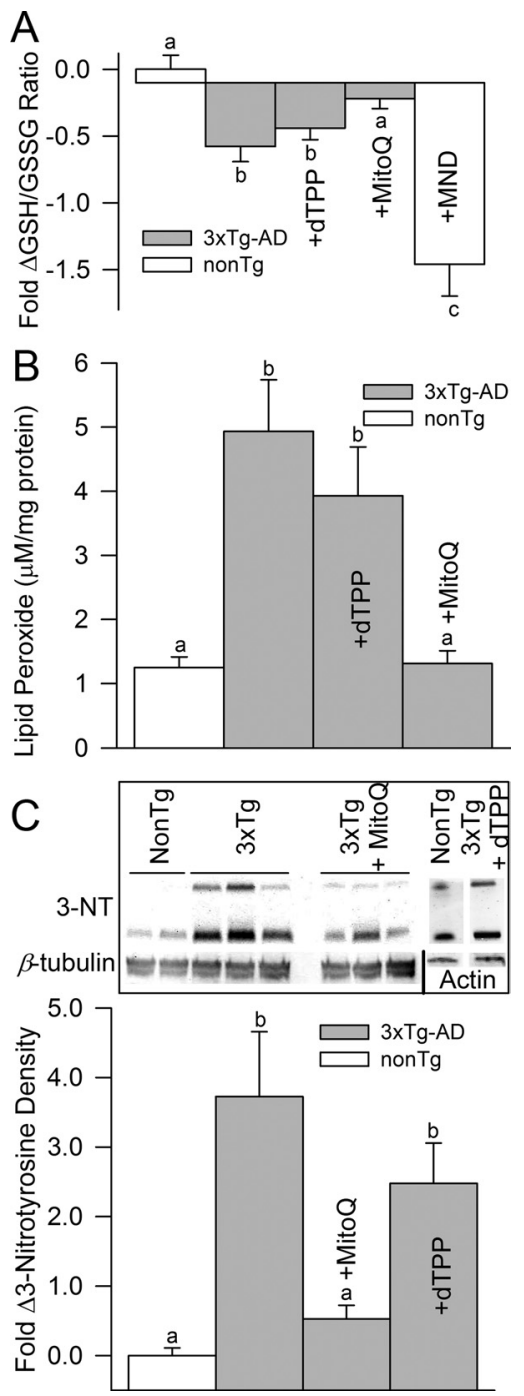

Figure 4. Mito $Q$ prevented oxidative stress in the brains of young female 3xTg-AD mice. $A$, MitoQ treatment inhibited decreased GSH/GSSG ratios in the brains of $3 \times \operatorname{Tg}-\operatorname{AD}$ mice $(p<0.01)$. As a positive control, nonTg samples were incubated with $40 \mu \mathrm{m}$ of the $\mathrm{O}_{2}^{-}$and, by dismutation, $\mathrm{H}_{2} \mathrm{O}_{2}$ generator menadione (MND) for $45-60$ min before the assay to oxidize GSH to GSSG (Di Monte et al., 1984). The results are expressed as fold decrease of GSH/GSSH from control level in nonTg brains. $n=6-10$ brains. $B$, Mito $Q$ treatment prevented increased lipid peroxidation (MDA levels) in the brains of $3 \times \mathrm{Tg}-\mathrm{AD}$ mice $(p<0.01)$. MDA levels were determined by the TBARS assay. $n=6$ brains for each except dTPP in which $n=3$ brains. C, Mito Q treatment suppressed the development of elevated levels of 3-NT in the brains of 3xTg-AD mice. Top, Representative immunoblots showing that 3-NT levels were higher in two proteins in the brains of 3xTg-AD mice than they were in the same proteins in nonTg mice. 3-NT levels in these proteins were lower in the brains of Mito Q-treated $3 \times \mathrm{XTg}-\mathrm{AD}$ animals than in untreated or dTPPtreated ones. Bottom, Quantitative analysis of 3-NT band density indicated that nitrated proteins were significantly increased in untreated 3xTg-AD mice at 7 months of age and that this increase was prevented by Mito $Q$ treatment. Density was determined for entire lanes and is shown as fold change from the average density in nonTg brains. $n=5-6$ brains. The brains used in this and subsequent assays were obtained from the 7-month-old female mice (Fig. 3) that had been treated as indicated for 5 months. Brains were removed 2 weeks after the end of MWM probe trials.

were decreased levels of GSH, increased levels of GSSG, and increased levels of malondialdehyde (MDA), a marker for lipid peroxidation. Figure $4 \mathrm{~A}$ shows that 5 months of MitoQ treatment prevented the decrease in the GSH/GSSG ratios found in the brains of the $3 \mathrm{xTg}-\mathrm{AD}$ mice. Figure $4 B$ shows that it had a similar effect on the increased MDA levels in the brains of these mice.

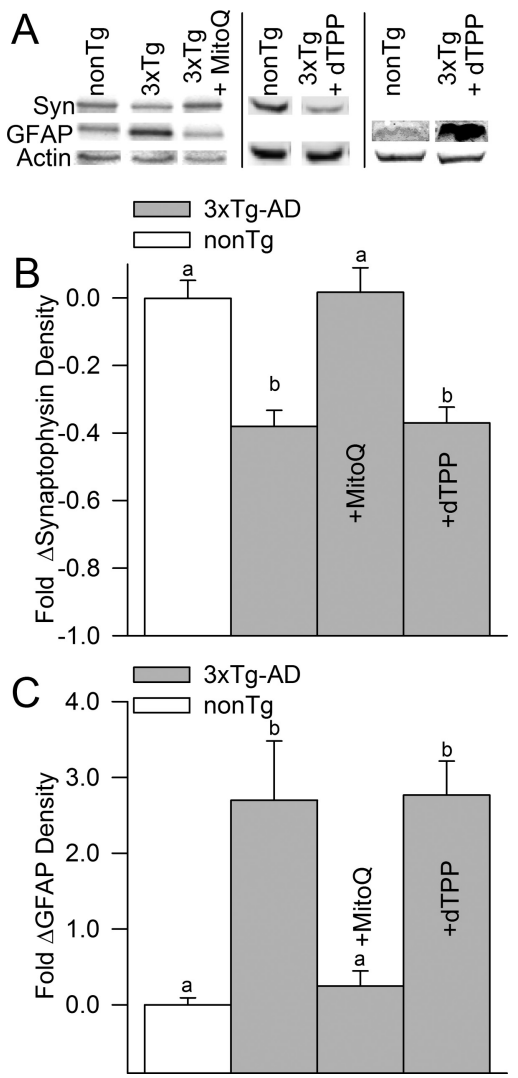

Figure 5. Mito Q prevented synaptic loss and proliferation of reactive astrocytes in the brains of young female $3 \times T g-A D$ mice. $A$, Immunoblots demonstrating that MitoQ prevented loss of the synaptic protein synaptophysin (Syn) and increase of the astrocyte marker GFAP in the brains of 3xTg-AD mice. Blots between lines are all from the same gel. Similar amounts of protein, as determined by the Bradford assay, were loaded onto the gels. Decreases in synaptophysin $(\boldsymbol{B})$ and increases in GFAP $(\boldsymbol{C})$ in the brains of $3 \times \mathrm{xT}$-AD mice as normalized to the levels in wild-type mice were blocked by Mito $Q$ treatment. $n=4-9$ brains for synaptophysin and $3-8$ brains for GFAP.

Lipid-derived radicals may contribute to nitration of proteins associated with biological membranes (Bartesaghi et al., 2010). Nitro-oxidative modification to proteins may dramatically alter their structure and biological activity and may play an important role in $\mathrm{AD}$ development. Because of the apparent decrease in $\mathrm{ONOO}^{-}$-associated RS levels in our in vitro analysis of MitoQtreated neurons, we investigated a related effect of MitoQ in vivo by measuring nitrotyrosine levels in 3xTg-AD mouse brains. Tyrosine nitration provides a footprint for free radical-mediated damage involving oxidation of $\mathrm{NO}^{*}$ to $\mathrm{ONOO}^{-}$or products of its subsequent decomposition and the formation of a tyrosyl radical intermediate (Halliwell and Gutteridge, 2007; Malinski, 2007). MitoQ prevented an increase in 3 -NT in young $3 \mathrm{xTg}$-AD brains (Fig. $4 C$ ). Together, the data indicate that the brains of young 3xTg-AD mice are under oxidative stress and that MitoQ treatment prevented this stress from occurring.

The likely cause of the decline in cognitive function of $3 \mathrm{xTg}-\mathrm{AD}$ mice with age is an increase in age-related synaptic dysfunction in their brains (Oddo et al., 2003b). Associated with this decreased synaptic efficacy is a decline in brain levels of the ubiquitous presynaptic marker synaptophysin, suggesting an actual loss of synapses (Blanchard et al., 2010). Figure 5, $A$ and $B$, shows that 5 months of MitoQ treatment prevented loss of synaptophysin in young $3 \mathrm{xTg}-\mathrm{AD}$ brains. This finding suggests that the prevention of the decline in cognitive function by MitoQ was secondary to preservation of functional synapses. 
The brains of human $\mathrm{AD}$ patients exhibit extensive astrogliosis, a process indicative of neuronal damage. Astrogliosis also occurs with increasing age in the brains of 3xTg-AD mice (Oddo et al., 2003a). We used the astrocyte marker GFAP to compare astrogliosis in the brains of nonTg and $3 \times \mathrm{Tg}-\mathrm{AD}$ mice. As reported previously (Oddo et al., 2003a), we found that the brains of the transgenic mice had higher levels of GFAP than did those of nonTg mice (Fig. 5C), indicating that they had more reactive astrocytes than did the wild-type brains. The brains of 3xTg-AD animals that had received 5 months of MitoQ treatment had GFAP levels identical to those found in the wild-type brains.

\section{Mito Q decreased $\mathrm{A} \beta$ accumulation in the brains of $3 \times \mathrm{Tg}-\mathrm{AD}$ mice}

The amyloid hypothesis states that $\mathrm{A} \beta$ peptides lie upstream of all the pathological events occurring in $\mathrm{AD}$, including NFT formation, synaptic dysfunction, and neuronal death (Oddo et al., 2003b; Hardy, 2006). This hypothesis is supported by the early $\mathrm{A} \beta$ accumulation in the rare, autosomal dominant forms of $\mathrm{AD}$, by transgenic mice harboring these human mutations (Hardy and Selkoe, 2002), and by recent studies suggesting that mitochondrial A $\beta$ may be responsible for synaptic degeneration and the onset of cognitive impairment in $\mathrm{AD}$ models of $\mathrm{A} \beta$ enrichment (Zhao et al., 2010). A $\beta$ appears to enhance production of cellular RS, and these RS in turn may to contribute to A $\beta$ toxicity. Evidence also suggests that not only does $A \beta$ increase cellular RS but that these RS may in turn increase production of $\mathrm{A} \beta$ in a destructive autocatalytic cycle (Misonou et al., 2000; Tamagno et al., 2002, 2005; Lin and Beal, 2006; Quiroz-Baez et al., 2009). Given the possible role of the mitochondria-generated RS in A $\beta$ production, we sought to determine the effect of MitoQ treatment on A $\beta$ burden (Cardoso et al., 2001; Hansson et al., 2004; Caspersen et al., 2005; Manczak et al., 2006; Anandatheerthavarada and Devi, 2007). Intraneuronal $A \beta$ immunoreactivity is one of the earliest histopathological events reported in the $3 \times$ Tg-AD brain (Billings et al., 2005). Figure $6 A$ shows that 7-month-old 3xTg-AD mice that had received MitoQ treatment for 5 months exhibited reduced intraneuronal staining by an anti-A $\beta_{(1-42)}$ antibody in their hippocampus and neocortex compared with untreated $3 \times \mathrm{Tg}-\mathrm{AD}$ mice. The ability of MitoQ to decrease soluble $\mathrm{A} \beta_{(1-42)}$ burden in the brains of $3 \mathrm{xTg}-\mathrm{AD}$ mice was investigated by ELISA. MitoQ decreased soluble $\mathrm{A} \beta_{(1-42)}$ in the brains of these animals (Fig. $6 B$ ). These findings are consistent with the hypothesis that an autocatalytic feedback cycle exists between $\mathrm{A} \beta$ deposition and oxidative stress.

\section{MitoQ decreased caspase activation in the cortex of 3xTg-AD mice}

Considerable evidence suggests that toxicity induced by both endogenous $\mathrm{A} \beta$ and extracellularly applied $\mathrm{A} \beta$ is mediated, at least in part, via the intrinsic, mitochondria-dependent apoptotic pathway (Harada and Sugimoto, 1999; Cardoso et al., 2001; Casley et al., 2002b; Caspersen et al., 2005; Hansson Petersen et al., 2008; Cho et al., 2009; Takuma et al., 2009). Recent evidence suggests that executioner caspases 3 and 7 may contribute to tau, the protein responsible for forming NFTs, pathology by cleaving tau after Asp421 to yield a cytotoxic $\Delta$ tau fragment (Rissman et al., 2004; Rohn et al., 2008; de Calignon et al., 2010). Because the intrinsic apoptotic pathway may involve mitochondrial RS generation (Kirkland et al., 2001), we hypothesized that the decrease in oxidative stress caused by MitoQ treatment may prevent aberrant caspase activity in the 3xTg-AD model (Rohn et al., 2008). Using a proluminescent caspase $3 / 7$ substrate, we measured the
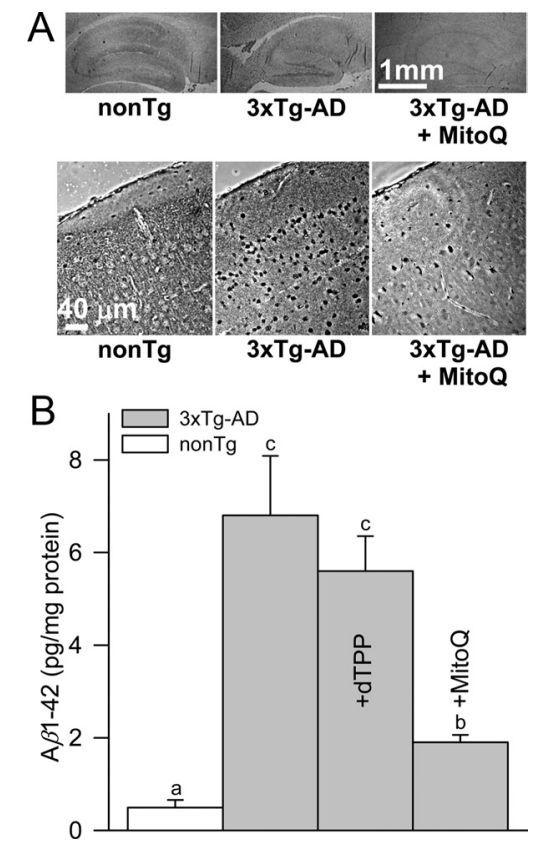

Figure 6. Mito $Q$ reduced $A \beta_{(1-42)}$ burden in brains of young $3 \times \operatorname{Tg}-A D$ mice. $A$, Representative photomicrographs showing immunostaining with an anti-A $\beta_{(1-42)}$ antibody within the hippocampus (top) and neocortex (bottom) of nonTg, untreated 3xTg-AD mice and 3xTg-AD mice that had received Mito $Q$ treatment for 5 months. Many cells in $3 \times T g-A D$ mice receiving no treatment exhibited cytosolic staining, whereas $3 \times \mathrm{XTg}-\mathrm{AD}$ mice that had received Mito $\mathrm{Q}$ treatment exhibited much less staining. Sections are representative of four brains per condition. $\boldsymbol{B}$, Quantification of soluble $A \beta_{(1-42)}$ by ELISA revealed that Mito $Q$ treatment prevented increased $\mathrm{A} \beta_{(1-42)}$ burden in the $3 \times \mathrm{Tg}-\mathrm{AD}$ mouse brain. $n=4$ brains for each condition.

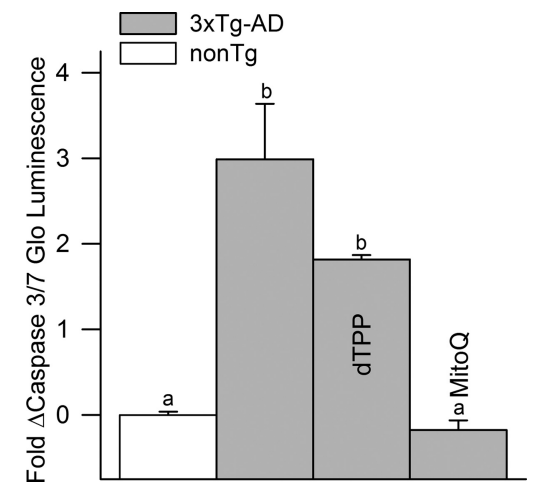

Figure 7. Mito 0 treatment blocked increased caspase $3 / 7$ activity in young female $3 \times T g-A D$ mouse brains. Caspase 3/7 activity was assessed by the Caspase-Glo 3/7 assay. Brain homogenates were incubated with a proluminescent caspase $3 / 7$-specific substrate and luminescence quantified by a luminometer. More intense luminescence indicates higher caspase $3 / 7$ activity. Values are normalized to the average luminescence of the nonTg controls. $n=8-10$ brains.

effect of MitoQ treatment on caspase 3/7 activity in the brains of young female $3 \mathrm{xTg}-\mathrm{AD}$ mice. There was a $3.0 \pm 0.6$-fold increase in cerebral caspase $3 / 7$ activity in 7 -month-old untreated $3 \times \mathrm{Tg}-\mathrm{AD}$ mice compared with nonTg controls. This increase was completely blocked by treatment with MitoQ during the preceding 5 months (Fig. 7).

\section{Discussion}

The recent development of antioxidants that selectively concentrate in mitochondria provides an opportunity to decipher the impact of mitochondria-generated RS on the pathogenesis and progression of both sporadic and inherited forms of AD (Smith et 
al., 2003; Lin and Beal, 2006; Reddy, 2008; Swerdlow and Khan, 2009; Moreira et al., 2010). The most extensively studied compound of this class is the mitochondria-targeted ubiquinone derivative MitoQ (Smith et al., 2003; James et al., 2007; RodriguezCuenca et al., 2010). We first investigated the ability of MitoQ to prevent the $\mathrm{A} \beta$-induced death of cortical neurons in cell culture. Low nanomolar concentrations of MitoQ prevented this death. These concentrations also blocked an $\mathrm{A} \beta$-induced increase in $\mathrm{NO}^{\circ}$-associated RS and $\mathrm{A} \beta$-induced depolarization of $\Delta \psi_{m}$. The data suggest that the death was associated with mitochondrial dysfunction and that it was caused by mitochondrial-derived RS. We next tested the ability of MitoQ to inhibit the cognitive deficits that occur in the $3 \mathrm{xTg}-\mathrm{AD}$ transgenic mouse model of $\mathrm{AD}$ from 2-7 months after birth (Oddo et al., 2003b). MitoQ prevented the decline in spatial memory retention in these animals during this period. $A \beta$ deposition and early cognitive impairment are preceded by mitochondrial dysfunction and increased oxidative stress in 3xTg-AD mouse brains (Resende et al., 2008; Yao et al., 2009). MitoQ blocked the elevated oxidative stress and also prevented synaptic loss, astrogliosis, increased $\mathrm{A} \beta$ burden, and elevated caspase 3/7 activity. These findings are consistent with a role for $\mathrm{A} \beta$-induced oxidative stress in mediating the cognitive deficits and neuropathology in these animals. They are also consistent with oxidative stress increasing $\mathrm{A} \beta$ burden and suggest an autocatalytic cycle in which $\mathrm{A} \beta$ increases RS, which then cause elevated levels of $\mathrm{A} \beta$.

Consistent with a role for mitochondrial-produced RS in AD, reduction of mitochondrial superoxide dismutase (MnSOD) levels accelerates $\mathrm{AD}$-like pathology in a transgenic mouse model of AD, whereas overexpression of MnSOD decreases $\mathrm{A} \beta$-processing, preserves synaptic integrity, and eliminates the earliest cognitive deficits in a transgenic mouse AD model (Li et al., 2004; Esposito et al., 2006; Massaad et al., 2009). The ubiquinone moiety of MitoQ reacts rapidly with $\mathrm{O}_{2}^{--}$and, thus, may enhance mitochondrial antioxidant defense by complimenting $\mathrm{O}_{2}^{--}$degradation by MnSOD (Maroz et al., 2009). MitoQ may also prevent damage downstream of $\mathrm{O}_{2}^{\cdot-}$ by directly detoxifying lipid-derived radicals and reactive nitrogen species or indirectly through effective recycling of $\alpha$-tocopherol (James et al., 2005, 2007).

Nitro-oxidative modifications to mitochondrial proteins are associated with pathological changes in mitochondrial redox state, morphology, and bioenergetics in preclinical and early $\mathrm{AD}$ patients (Velliquette et al., 2005; Anantharaman et al., 2006; Butterfield et al., 2006, 2007; Yao et al., 2009). Evidence supports a causative role for these modifications in mediating the early synaptic degeneration and cognitive decline in $\mathrm{AD}$ (Wang et al., 2008b; Dumont et al., 2009; Massaad et al., 2009; Yao et al., 2009). Modification of mitochondrial enzymes and components of the respiratory chain by RS may contribute to impaired glucose metabolism found in preclinical AD subjects (Sultana and Butterfield, 2009; Yao et al., 2009). Longitudinal neuroimaging studies reveal the rate of metabolic decline within the medial temporal lobe predicts the progression of cognitive deterioration from normal aging to $\mathrm{AD}$ and more closely correlates with the level of oxidative damage than other biomarkers tested in preclinical patients (Mosconi et al., 2008a,b). This correlation may prove fundamental because mitochondrial dysfunction and oxidative stress may encourage the development of amyloid plaques and NFTs (Hardy, 2006; Gibson and Shi, 2010).

The predominant pathway of $\mathrm{A} \beta$ production occurs by sequential cleavage of APP by $\beta$ - and $\gamma$-secretases. Metabolic impairment induced by thiamine deficiency or respiratory chain inhibition augments $\beta$-secretase expression and activity (Karuppagounder et al., 2009; Zhang et al., 2011). Oxidative stress also induces $\beta$-secretase upregulation and, consequently, increased $\mathrm{A} \beta$ generation, both of which are preventable by antioxidant treatment in vitro (Tamagno et al., 2002, 2005; Tong et al., 2005). The final step in $\mathrm{A} \beta$ production is achieved by $\gamma$-secretase, which is present in mitochondria and may also be upregulated by RS (Minopoli et al., 2007; Guglielmotto et al., 2010; Oda et al., 2010). Mitochondrial RS also activates caspases, which may generate A $\beta$ by directly cleaving APP (caspase 3 ) or via a process involving $\gamma$-secretase (caspases 2 and 8; Newcombe et al., 2004; Chae et al., 2010). Oxidative stress may also contribute to $A \beta$ accumulation by inactivating $A \beta$-degrading enzymes (Shinall et al., 2005). Intracellular $\mathrm{A} \beta$ may then enter the mitochondria in which it induces additional RS and magnifies the metabolic deficit (Lustbader et al., 2004; Hansson Petersen et al., 2008). MitoQ treatment may break this putative autocatalytic cycle.

The attenuation of increased caspase 3/7 activity by MitoQ treatment may modulate tau pathology, because the early cleavage of tau by these caspases initiates tau aggregation and phosphorylation and may contribute to cognitive decline (Cotman et al., 2005; de Calignon et al., 2010). As reported by others, $\Delta$ tau levels were below the detectable level in our 7-month-old, untreated 3xTg-AD mice (data not shown; Rissman et al., 2004). It will be of interest to treat these mice for longer periods (e.g., 18 months) with MitoQ to determine whether it can ameliorate development of tau pathology.

The results reported here highlight a possible influence of mitochondria-induced oxidative stress on cognitive decline and neuropathology in AD. Failure to address underlying mitochondrial deficits may explain the disappointing results of $\mathrm{A} \beta$ centered therapy in humans. Recent clinical trials attempting to replicate the benefits of $A \beta$ immunotherapy seen in mouse models have been primarily unsuccessful in preventing early cognitive decline in $\mathrm{AD}$ patients despite significantly decreasing the amyloid burden (Holmes et al., 2008; Sabbagh, 2009). Others describe a lack of clinical correlation between $\mathrm{A} \beta$ levels and $\mathrm{AD}$ progression and propose that brain atrophy and cerebral metabolic rate provide the best predictive parameters for clinical changes in $\mathrm{AD}$ (Giannakopoulos et al., 2003; Li et al., 2008; Walhovd et al., 2010). Thus, $\mathrm{A} \beta$ may not exclusively dictate $\mathrm{AD}$ pathogenesis, and auxiliary approaches may be required for optimal therapeutic benefit and the effective prevention of $\mathrm{AD}$.

Several antioxidants are reported to lessen pathologies found in transgenic mouse models of AD (Lim et al., 2001; Stackman et al., 2003; Nicolakakis et al., 2008; Wang et al., 2008a). However, these antioxidants are nonspecific and should interact with ROS in all areas of the brain. Our study is a significant step forward from these in that it shows that an antioxidant that only operates within mitochondria is protective. In addition, this is the first demonstration that a mitochondria-targeted therapy is effective in vivo and opens the way for translation to patients (MitoQ has been though two phase II trials for other conditions; Snow et al., 2010). The ability of MitoQ to prevent neuropathologies in $3 \times \mathrm{Tg}-\mathrm{AD}$ mice also suggest that in vivo assessments of other classes of mitochondria-targeted antioxidants for treating $\mathrm{AD}$, such as SS31 peptide, are warranted (Manczak et al., 2010).

\section{References}

Adlam VJ, Harrison JC, Porteous CM, James AM, Smith RA, Murphy MP, Sammut IA (2005) Targeting an antioxidant to mitochondria decreases cardiac ischemia-reperfusion injury. FASEB J 19:1088-1095.

Anandatheerthavarada HK, Devi L (2007) Amyloid precursor protein 
and mitochondrial dysfunction in Alzheimer's disease. Neuroscientist 13:626-638.

Anandatheerthavarada HK, Biswas G, Robin MA, Avadhani NG (2003) Mitochondrial targeting and a novel transmembrane arrest of Alzheimer's amyloid precursor protein impairs mitochondrial function in neuronal cells. J Cell Biol 161:41-54.

Anantharaman M, Tangpong J, Keller JN, Murphy MP, Markesbery WR, Kiningham KK, St Clair DK (2006) $\beta$-Amyloid mediated nitration of manganese superoxide dismutase: implication for oxidative stress in a APP ${ }^{\text {NLh/NLh }}$ X PS-1 ${ }^{\text {P264L/P264L }}$ double knock-in mouse model of Alzheimer's disease. Am J Pathol 168:1608-1618.

Arendash GW, Schleif W, Rezai-Zadeh K, Jackson EK, Zacharia LC, Cracchiolo JR, Shippy D, Tan J (2006) Caffeine protects Alzheimer's mice against cognitive impairment and reduces brain beta-amyloid production. Neuroscience 142:941-952.

Asin-Cayuela J, Manas AR, James AM, Smith RA, Murphy MP (2004) Finetuning the hydrophobicity of a mitochondria-targeted antioxidant. FEBS Lett 571:9-16.

Bartesaghi S, Wenzel J, Trujillo M, López M, Joseph J, Kalyanaraman B, Radi $\mathrm{R}$ (2010) Lipid peroxyl radicals mediate tyrosine dimerization and nitration in membranes. Chem Res Toxicol 23:821-835.

Beckman JS, Koppenol WH (1996) Nitric oxide, superoxide, and peroxynitrite: the good, the bad, and the ugly. Am J Physiol 271:C1424-C1437.

Billings LM, Oddo S, Green KN, McGaugh JL, LaFerla FM (2005) Intraneuronal $\mathrm{A} \beta$ causes the onset of early Alzheimer's disease-related cognitive deficits in transgenic mice. Neuron 45:675-688.

Blanchard J, Wanka L, Tung YC, Cárdenas-Aguayo Mdel C, LaFerla FM, Iqbal K, Grundke-Iqbal I (2010) Pharmacologic reversal of neurogenic and neuroplastic abnormalities and cognitive impairments without affecting $\mathrm{A} \beta$ and tau pathologies in $3 \mathrm{xTg}-\mathrm{AD}$ mice. Acta Neuropathol 120:605-621.

Buccafusco J (2001) Spatial navigation (water maze) tasks. In: Methods of behavior analysis in neuroscience (Terry A, ed), pp 164-177. Boca Raton, FL: CRC.

Butterfield DA, Perluigi M, Sultana R (2006) Oxidative stress in Alzheimer's disease brain: new insights from redox proteomics. Eur J Pharmacol 545:39-50.

Butterfield DA, Reed T, Newman SF, Sultana R (2007) Roles of amyloid $\beta$-peptide-associated oxidative stress and brain protein modifications in the pathogenesis of Alzheimer's disease and mild cognitive impairment. Free Radic Biol Med 43:658-677.

Canevari L, Clark JB, Bates TE (1999) $\beta$-Amyloid fragment 25-35 selectively decreases complex IV activity in isolated mitochondria. FEBS Lett 457:131-134.

Cardoso SM, Santos S, Swerdlow RH, Oliveira CR (2001) Functional mitochondria are required for amyloid $\beta$-mediated neurotoxicity. FASEB J 15:1439-1441.

Casley CS, Canevari L, Land JM, Clark JB, Sharpe MA (2002a) $\beta$-Amyloid inhibits integrated mitochondrial respiration and key enzyme activities. J Neurochem 80:91-100.

Casley CS, Land JM, Sharpe MA, Clark JB, Duchen MR, Canevari L (2002b) $\beta$-amyloid fragment 25-35 causes mitochondrial dysfunction in primary cortical neurons. Neurobiol Dis 10:258-267.

Caspersen C, Wang N, Yao J, Sosunov A, Chen X, Lustbader JW, Xu HW, Stern D, McKhann G, Yan SD (2005) Mitochondrial A $\beta$ : a potential focal point for neuronal metabolic dysfunction in Alzheimer's disease. FASEB J 19:2040-2041.

Chacko BK, Reily C, Srivastava A, Johnson MS, Ye Y, Ulasova E, Agarwal A, Zinn KR, Murphy MP, Kalyanaraman B, Darley-Usmar V (2010) Prevention of diabetic nephropathy in Ins2+/- AkitaJ mice by the mitochondria-targeted therapy MitoQ. Biochem J 432:9-19.

Chae SS, Yoo CB, Jo C, Yun SM, Jo SA, Koh YH (2010) Caspases-2 and -8 are involved in the presenilin1/gamma-secretase-dependent cleavage of amyloid precursor protein after the induction of apoptosis. J Neurosci Res 88:1926-1933.

Cho DH, Nakamura T, Fang J, Cieplak P, Godzik A, Gu Z, Lipton SA (2009) S-nitrosylation of Drp1 mediates $\beta$-amyloid-related mitochondrial fission and neuronal injury. Science 324:102-105.

Clinton LK, Billings LM, Green KN, Caccamo A, Ngo J, Oddo S, McGaugh JL, LaFerla FM (2007) Age-dependent sexual dimorphism in cognition and stress response in the $3 \times \mathrm{Tg}-\mathrm{AD}$ mice. Neurobiol Dis 28:76-82.

Cotman CW, Poon WW, Rissman RA, Blurton-Jones M (2005) The role of caspase cleavage of tau in Alzheimer disease neuropathology. J Neuropath Exp Neurol 64:104-112.

de Calignon A, Fox LM, Pitstick R, Carlson GA, Bacskai BJ, Spires-Jones TL, Hyman BT (2010) Caspase activation precedes and leads to tangles. Nature 464:1201-1204.

DeKosky ST, Williamson JD, Fitzpatrick AL, Kronmal RA, Ives DG, Saxton JA, Lopez OL, Burke G, Carlson MC, Fried LP, Kuller LH, Robbins JA, Tracy RP, Woolard NF, Dunn L, Snitz BE, Nahin RL, Furberg CD; Ginkgo Evaluation of Memory Study Investigators (2008) Ginkgo biloba for prevention of dementia: a randomized controlled trial. JAMA 300:2253-2262.

Díaz A, De Jesús L, Mendieta L, Calvillo M, Espinosa B, Zenteno E, Guevara J, Limón ID (2010) The amyloid- $\beta 25-35$ injection into the CA1 region of the neonatal rat hippocampus impairs the long-term memory because of an increase of nitric oxide. Neurosci Lett 468:151-155.

Di Monte D, Ross D, Bellomo G, Eklöw L, Orrenius S (1984) Alterations in intracellular thiol homeostasis during the metabolism of menadione by isolated rat hepatocytes. Arch Biochem Biophys 235:334-342.

Duchen MR (1999) Contributions of mitochondria to animal physiology: from homeostatic sensor to calcium signalling and cell death. J Physiol 516:1-17.

Dumont M, Wille E, Stack C, Calingasan NY, Beal MF, Lin MT (2009) Reduction of oxidative stress, amyloid deposition, and memory deficit by manganese superoxide dismutase overexpression in a transgenic mouse model of Alzheimer's disease. FASEB J 23:2459-2466.

Esposito L, Raber J, Kekonius L, Yan F, Yu GQ, Bien-Ly N, Puoliväli J, Scearce-Levie K, Masliah E, Mucke L (2006) Reduction in mitochondrial superoxide dismutase modulates Alzheimer's disease-like pathology and accelerates the onset of behavioral changes in human amyloid precursor protein transgenic mice. J Neurosci 26:5167-5179.

Giannakopoulos P, Herrmann FR, Bussière T, Bouras C, Kövari E, Perl DP, Morrison JH, Gold G, Hof PR (2003) Tangle and neuron numbers, but not amyloid load, predict cognitive status in Alzheimer's disease. Neurology 60:1495-1500.

Gibson GE, Shi Q (2010) A mitocentric view of Alzheimer's disease suggests multi-faceted treatments. J Alzheimers Dis 20:S591-S607.

Graham D, Huynh NN, Hamilton CA, Beattie E, Smith RA, Cochemé HM, Murphy MP, Dominiczak AF (2009) Mitochondria-targeted antioxidant $\mathrm{Mito}_{10}$ improves endothelial function and attenuates cardiac hypertrophy. Hypertension 54:322-328.

Grundman M, Petersen RC, Ferris SH, Thomas RG, Aisen PS, Bennett DA, Foster NL, Jack CR Jr, Galasko DR, Doody R, Kaye J, Sano M, Mohs R, Gauthier S, Kim HT, Jin S, Schultz AN, Schafer K, Mulnard R, van Dyck $\mathrm{CH}$, Mintzer J, Zamrini EY, Cahn-Weiner D, Thal LJ; Alzheimer's Disease Cooperative Study (2004) Mild cognitive impairment can be distinguished from Alzheimer disease and normal aging for clinical trials. Arch Neurol 61:59-66.

Guglielmotto M, Giliberto L, Tamagno E, Tabaton M (2010) Oxidative stress mediates the pathogenic effect of different Alzheimer's disease risk factors. Front Aging Neurosci 2:3.

Halliwell B, Gutteridge JMC (2007) Free radicals in biology and medicine, Ed 4. Oxford, UK: Oxford UP.

Hansson CA, Frykman S, Farmery MR, Tjernberg LO, Nilsberth C, Pursglove SE, Ito A, Winblad B, Cowburn RF, Thyberg J, Ankarcrona M (2004) Nicastrin, presenilin, APH-1, and PEN-2 form active $\gamma$-secretase complexes in mitochondria. J Biol Chem 279:51654-51660.

Hansson Petersen CA, Alikhani N, Behbahani H, Wiehager B, Pavlov PF, Alafuzoff I, Leinonen V, Ito A, Winblad B, Glaser E, Ankarcrona M (2008) The amyloid $\beta$-peptide is imported into mitochondria via the TOM import machinery and localized to mitochondrial cristae. Proc Natl Acad Sci USA 105:13145-13150.

Harada J, Sugimoto M (1999) Activation of caspase-3 in $\beta$-amyloidinduced apoptosis of cultured rat cortical neurons. Brain Res 842:311-323.

Hardy J (2006) A hundred years of Alzheimer's disease research. Neuron 52:3-13.

Hardy J, Selkoe DJ (2002) The amyloid hypothesis of Alzheimer's disease: progress and problems on the road to therapeutics. Science 297:353-356.

Hensley K, Carney JM, Mattson MP, Aksenova M, Harris M, Wu JF, Floyd RA, Butterfield DA (1994) A model for $\beta$-amyloid aggregation and neurotoxicity based on free radical generation by the peptide: relevance to Alzheimer's disease. Proc Natl Acad Sci USA 91:3270-3274.

Hirai K, Aliev G, Nunomura A, Fujioka H, Russell RL, Atwood CS, Johnson 
AB, Kress Y, Vinters HV, Tabaton M, Shimohama S, Cash AD, Siedlak SL, Harris PL, Jones PK, Petersen RB, Perry G, Smith MA (2001) Mitochondrial abnormalities in Alzheimer's disease. J Neurosci 21:3017-3023.

Holmes C, Boche D, Wilkinson D, Yadegarfar G, Hopkins V, Bayer A, Jones RW, Bullock R, Love S, Neal JW, Zotova E, Nicoll JA (2008) Long-term effects of $A \beta 42$ immunisation in Alzheimer's disease: follow-up of a randomised, placebo-controlled phase I trial. Lancet 372:216-223.

Hoyer S (1996) Oxidative metabolism deficiencies in brains of patients with Alzheimer's disease. Acta Neurol Scand Suppl 165:18-24.

James AM, Cochemé HM, Smith RA, Murphy MP (2005) Interactions of mitochondria-targeted and untargeted ubiquinones with the mitochondrial respiratory chain and reactive oxygen species. J Biol Chem 280:21295-21312.

James AM, Sharpley MS, Manas AR, Frerman FE, Hirst J, Smith RA, Murphy MP (2007) Interaction of the mitochondria-targeted antioxidant MitoQ with phospholipid bilayers and ubiquinone oxidoreductases: implications for the use of exogenous ubiquinones as therapies and experimental tools. J Biol Chem 282:14708-14718.

Jang JH, Surh YJ (2003) Protective effect of resveratrol on $\beta$-amyloidinduced oxidative PC12 cell death. Free Radic Biol Med 34:1100-1110.

Jauslin ML, Meier T, Smith RA, Murphy MP (2003) Mitochondria-targeted antioxidants protect Friedreich Ataxia fibroblasts from endogenous oxidative stress more effectively than untargeted antioxidants. FASEB J 17:1972-1974.

Karuppagounder SS, Xu H, Shi Q, Chen LH, Pedrini S, Pechman D, Baker H, Beal MF, Gandy SE, Gibson GE (2009) Thiamine deficiency induces oxidative stress and exacerbates the plaque pathology in Alzheimer's mouse model. Neurobiol Aging 30:1587-1600.

Keil U, Bonert A, Marques CA, Scherping I, Weyermann J, Strosznajder JB, Müller-Spahn F, Haass C, Czech C, Pradier L, Müller WE, Eckert A (2004) Amyloid $\beta$-induced changes in nitric oxide production and mitochondrial activity lead to apoptosis. J Biol Chem 279:50310-50320.

Keller JN, Kindy MS, Holtsberg FW, St Clair DK, Yen HC, Germeyer A, Steiner SM, Bruce-Keller AJ, Hutchins JB, Mattson MP (1998) Mitochondrial manganese superoxide dismutase prevents neural apoptosis and reduces ischemic brain injury: suppression of peroxynitrite production, lipid peroxidation, and mitochondrial dysfunction. J Neurosci 18:687-697.

Kelso GF, Porteous CM, Coulter CV, Hughes G, Porteous WK, Ledgerwood EC, Smith RA, Murphy MP (2001) Selective targeting of a redox-active ubiquinone to mitochondria within cells. Antioxidant and antiapoptotic properties. J Biol Chem 276:4588-4596.

Kim HS, Lee JH, Lee JP, Kim EM, Chang KA, Park CH, Jeong SJ, Wittendorp MC, Seo JH, Choi SH, Suh YH (2002) Amyloid $\beta$ peptide induces cytochrome $c$ release from isolated mitochondria. Neuroreport 13:1989-1993.

Kirkland RA, Franklin JL (2001) Evidence for redox regulation of cytochrome $c$ release during programmed neuronal death: antioxidant effects of protein synthesis and caspase inhibition. J Neurosci 21:1949-1963.

Kirkland RA, Windelborn JA, Kasprzak JM, Franklin JL (2002) A Baxinduced pro-oxidant state is critical for cytochrome $c$ release during programmed neuronal death. J Neurosci 22:6480-6490.

Kirkland RA, Saavedra GM, Cummings BS, Franklin JL (2010) Bax regulates production of superoxide in both apoptotic and nonapoptotic neurons: role of caspases. J Neurosci 30:16114-16127.

Li F, Calingasan NY, Yu F, Mauck WM, Toidze M, Almeida CG, Takahashi RH, Carlson GA, Flint Beal M, Lin MT, Gouras GK (2004) Increased plaque burden in brains of APP mutant MnSOD heterozygous knockout mice. J Neurochem 89:1308-1312.

Liang JH, Du J, Xu LD, Jiang T, Hao S, Bi J, Jiang B (2009) Catalpol protects primary cultured cortical neurons induced by $\mathrm{A} \beta_{1-42}$ through a mitochondrial-dependent caspase pathway. Neurochem Int 55:741-746.

Li Y, Rinne JO, Mosconi L, Pirraglia E, Rusinek H, DeSanti S, Kemppainen N, Någren K, Kim BC, Tsui W, de Leon MJ (2008) Regional analysis of FDG and PIB-PET images in normal aging, mild cognitive impairment, and Alzheimer's disease. Eur J Nucl Med Mol Imaging 35:2169-2181.

Lim GP, Chu T, Yang F, Beech W, Frautschy SA, Cole GM (2001) The curry spice curcumin reduces oxidative damage and amyloid pathology in an Alzheimer transgenic mouse. J Neurosci 21:8370-8377.

Lin MT, Beal MF (2006) Mitochondrial dysfunction and oxidative stress in neurodegenerative diseases. Nature 443:787-795.

Liu D, Li C, Chen Y, Burnett C, Liu XY, Downs S, Collins RD, Hawiger J
(2004) Nuclear import of proinflammatory transcription factors is required for massive liver apoptosis induced by bacterial lipopolysaccharide. J Biol Chem 279:48434-48442.

Longo VD, Viola KL, Klein WL, Finch CE (2000) Reversible inactivation of superoxide-sensitive aconitase in A $\beta 1-42$-treated neuronal cell lines. J Neurochem 75:1977-1985.

Lowes DA, Thottakam BM, Webster NR, Murphy MP, Galley HF (2008) The mitochondria-targeted antioxidant MitoQ protects against organ damage in a lipopolysaccharide-peptidoglycan model of sepsis. Free Radic Biol Med 45:1559-1565.

Lustbader JW, Cirilli M, Lin C, Xu HW, Takuma K, Wang N, Caspersen C, Chen X, Pollak S, Chaney M, Trinchese F, Liu S, Gunn-Moore F, Lue LF, Walker DG, Kuppusamy P, Zewier ZL, Arancio O, Stern D, Yan SS, Wu H (2004) ABAD directly links A $\beta$ to mitochondrial toxicity in Alzheimer's disease. Science 304:448-452.

Malinski T (2007) Nitric oxide and nitroxidative stress in Alzheimer's disease. J Alzheimers Dis 11:207-218.

Manczak M, Anekonda TS, Henson E, Park BS, Quinn J, Reddy PH (2006) Mitochondria are a direct site of $A \beta$ accumulation in Alzheimer's disease neurons: implications for free radical generation and oxidative damage in disease progression. Hum Mol Genet 15:1437-1449.

Manczak M, Mao P, Calkins MJ, Cornea A, Reddy AP, Murphy MP, Szeto HH, Park B, Reddy PH (2010) Mitochondria-targeted antioxidants protect against amyloid- $\beta$ toxicity in Alzheimer's disease neurons. J Alzheimers Dis 20:S609-S631.

Maroz A, Anderson RF, Smith RA, Murphy MP (2009) Reactivity of ubiquinone and ubiquinol with superoxide and the hydroperoxyl radical: implications for in vivo antioxidant activity. Free Radic Biol Med 46:105-109.

Massaad CA, Washington TM, Pautler RG, Klann E (2009) Overexpression of SOD-2 reduces hippocampal superoxide and prevents memory deficits in a mouse model of Alzheimer's disease. Proc Natl Acad Sci USA 106:13576-13581.

Mazziotti M, Perlmutter DH (1998) Resistance to the apoptotic effect of aggregated amyloid- $\beta$ peptide in several different cell types including neuronal- and hepatoma-derived cell lines. Biochem J 332:517-524.

Minopoli G, Stante M, Napolitano F, Telese F, Aloia L, De Felice M, Di Lauro R, Pacelli R, Brunetti A, Zambrano N, Russo T (2007) Essential roles for Fe65, Alzheimer amyloid precursor-binding protein, in the cellular response to DNA damage. J Biol Chem 282:831-835.

Misonou H, Morishima-Kawashima M, Ihara Y (2000) Oxidative stress induces intracellular accumulation of amyloid $\beta$-protein $(A \beta)$ in human neuroblastoma cells. Biochemistry 39:6951-6959.

Moreira PI, Zhu X, Wang X, Lee HG, Nunomura A, Petersen RB, Perry G, Smith MA (2010) Mitochondria: a therapeutic target in neurodegeneration. Biochim Biophys Acta 1802:212-220.

Morris R (1984) Developments of a water-maze procedure for studying spatial learning in the rat. J Neurosci Methods 11:47-60.

Mosconi L, Pupi A, De Leon MJ (2008a) Brain glucose hypometabolism and oxidative stress in preclinical Alzheimer's disease. Ann NY Acad Sci 1147:180-195.

Mosconi L, De Santi S, Li J, Tsui WH, Li Y, Boppana M, Laska E, Rusinek H, de Leon MJ (2008b) Hippocampal hypometabolism predicts cognitive decline from normal aging. Neurobiol Aging 29:676-692.

Murphy MP, Smith RA (2007) Targeting antioxidants to mitochondria by conjugation to lipophilic cations. Annu Rev Pharmacol Toxicol $47: 629-656$.

Newcombe RE, Blumbergs PC, Sarvestani G, Manavis J, Jones NR (2004) Caspase-3-mediated proteolyis of amyloid precursor protein and the production of amyloid A-beta in human acute and chronic compressive myleopathy. J Bone Joint Surg Br 86B [Suppl IV]:462.

Nicholls DG, Budd SL (2000) Mitochondria and neuronal survival. Physiol Rev 80:315-360.

Nicholls DG, Ferguson SJ (2002) Bioenergetics 3. London, UK: Academic.

Nicholls DG, Ward MW (2000) Mitochondrial membrane potential and cell death: mortality and millivolts. Trends Neurosci 23:166-174.

Nicolakakis N, Aboulkassim T, Ongali B, Lecrux C, Fernandes P, Rosa-Neto P, Tong XK, Hamel E (2008) Complete rescue of cerebrovascular function in aged Alzheimer's disease transgenic mice by antioxidants and pioglitazone, a peroxisome proliferator-activated receptor $\gamma$ agonist. J Neurosci 28:9287-9296.

Oda A, Tamaoka A, Araki W (2010) Oxidative stress up-regulates presenilin 1 in lipid rafts in neuronal cells. J Neurosci Res 88:1137-1145. 
Oddo S, Caccamo A, Kitazawa M, Tseng BP, LaFerla FM (2003a) Amyloid deposition precedes tangle formation in a triple transgenic model of Alzheimer's disease. Neurobiol Aging 24:1063-1070.

Oddo S, Caccamo A, Shepherd JD, Murphy MP, Golde TE, Kayed R, Metherate R, Mattson MP, Akbari Y, LaFerla FM (2003b) Tripletransgenic model of Alzheimer's disease with plaques and tangles. Neuron 39:409-421.

Petersen RC, Thomas RG, Grundman M, Bennett D, Doody R, Ferris S, Galasko D, Jin S, Kaye J, Levey A, Pfeiffer E, Sano M, van Dyck CH, Thal LJ; Alzheimer's Disease Cooperative Study Group (2005) Vitamin E and donepezil for the treatment of mild cognitive impairment. N Engl J Med 352:2379-2388.

Pham DQ, Plakogiannis R (2005) Vitamin E supplementation in Alzheimer's disease, Parkinson's disease, tardive dyskinesia, and cataract. Part 2. Ann Pharmacother 39:2065-2072.

Pike CJ, Burdick D, Walencewicz AJ, Glabe CG, Cotman CW (1993) Neurodegeneration induced by $\beta$-amyloid peptides in vitro: the role of peptide assembly state. J Neurosci 13:1676-1687.

Pike CJ, Walencewicz-Wasserman AJ, Kosmoski J, Cribbs DH, Glabe CG, Cotman CW (1995) Structure-activity analyses of $\beta$-amyloid peptides: contributions of the $\beta 25-35$ region to aggregation and neurotoxicity. J Neurochem 64:253-265.

Quiroz-Baez R, Rojas E, Arias C (2009) Oxidative stress promotes JNKdependent amyloidogenic processing of normally expressed human APP by differential modification of $\alpha$-, $\beta$-, and $\gamma$-secretase expression. Neurochem Int 55:662-670.

Reddy PH (2008) Mitochondrial medicine for aging and neurodegenerative diseases. Neuromolecular Med 10:291-315.

Resende R, Moreira PI, Proença T, Deshpande A, Busciglio J, Pereira C, Oliveira CR (2008) Brain oxidative stress in a triple-transgenic mouse model of Alzheimer disease. Free Radic Biol Med 44:2051-2057.

Rhein V, Baysang G, Rao S, Meier F, Bonert A, Müller-Spahn F, Eckert A (2009) Amyloid-beta leads to impaired cellular respiration, energy production and mitochondrial electron chain complex activities in human neuroblastoma cells. Cell Mol Neurobiol 29:1063-1071.

Rinaldi P, Polidori MC, Metastasio A, Mariani E, Mattioli P, Cherubini A, Catani M, Cecchetti R, Senin U, Mecocci P (2003) Plasma antioxidants are similarly depleted in mild cognitive impairment and in Alzheimer's disease. Neurobiol Aging 24:915-919.

Rissman RA, Poon WW, Blurton-Jones M, Oddo S, Torp R, Vitek MP, LaFerla FM, Rohn TT, Cotman CW (2004) Caspase-cleavage of tau is an early event in Alzheimer disease tangle pathology. J Clin Invest 114:121-130.

Rodriguez-Cuenca S, Cochemé HM, Logan A, Abakumova I, Prime TA, Rose C, Vidal-Puig A, Smith AC, Rubinsztein DC, Fearnley IM, Jones BA, Pope S, Heales SJ, Lam BY, Neogi SG, McFarlane I, James AM, Smith RA, Murphy MP (2010) Consequences of long-term oral administration of the mitochondria-targeted antioxidant MitoQ to wild-type mice. Free Radic Biol Med 48:161-172.

Rohn TT, Vyas V, Hernandez-Estrada T, Nichol KE, Christie LA, Head E (2008) Lack of pathology in a triple transgenic mouse model of Alzheimer's disease after overexpression of the anti-apoptotic protein Bcl-2. J Neurosci 28:3051-3059.

Royall JA, Ischiropoulos H (1993) Evaluation of 2',7'-dichlorofluorescin and dihydrorhodamine 123 as fluorescent probes for intracellular $\mathrm{H}_{2} \mathrm{O}_{2}$ in cultured endothelial cells. Arch Biochem Biophys 302:348-355.

Sabbagh MN (2009) Drug development for Alzheimer's disease: where are we now and where are we headed? Am J Geriatr Pharmacother 7:167-185.

Sano M, Ernesto C, Thomas RG, Klauber MR, Schafer K, Grundman M, Woodbury P, Growdon J, Cotman CW, Pfeiffer E, Schneider LS, Thal LJ (1997) A controlled trial of selegiline, alpha-tocopherol, or both as treatment for Alzheimer's disease. N Engl J Med 336:1216-1222.

Saraiva LM, Seixas da Silva GS, Galina A, da-Silva WS, Klein WL, Ferreira ST, De Felice FG (2010) Amyloid- $\beta$ triggers the release of neuronal hexokinase 1 from mitochondria. PLos One 5:e15230.

Saretzki G, Murphy MP, von Zglinicki T (2003) MitoQ counteracts telomere shortening and elongates lifespan of fibroblasts under mild oxidative stress. Aging Cell 2:141-143.

Setsukinai K, Urano Y, Kakinuma K, Majima HJ, Nagano T (2003) Development of novel fluorescence probes that can reliably detect reactive oxygen species and distinguish specific species. J Biol Chem 278:3170-3175.
Shelat PB, Chalimoniuk M, Wang JH, Strosznajder JB, Lee JC, Sun AY, Simonyi A, Sun GY (2008) Amyloid beta peptide and NMDA induce ROS from NADPH oxidase and AA release from cytosolic phospholipase $\mathrm{A}_{2}$ in cortical neurons. J Neurochem 106:45-55.

Shigenaga MK, Hagen TM, Ames BN (1994) Oxidative damage and mitochondrial decay in aging. Proc Natl Acad Sci USA 91:10771-10778.

Shinall H, Song ES, Hersh LB (2005) Susceptibility of amyloid $\beta$ peptide degrading enzymes to oxidative damage: a potential Alzheimer's disease spiral. Biochemistry 44:15345-15350.

Smith RA, Murphy MP (2010) Animal and human studies with the mitochondria-targeted antioxidant MitoQ. Ann NY Acad Sci 1201:96-103.

Smith RA, Porteous CM, Gane AM, Murphy MP (2003) Delivery of bioactive molecules to mitochondria in vivo. Proc Natl Acad Sci USA 100:5407-5412.

Snow BJ, Rolfe FL, Lockhart MM, Frampton CM, O’Sullivan JD, Fung V, Smith RA, Murphy MP, Taylor KM; Protect Study Group (2010) A double-blind, placebo-controlled study to assess the mitochondriatargeted antioxidant MitoQ as a disease-modifying therapy in Parkinson's disease. Mov Disord 25:1670-1674.

Stackman RW, Eckenstein F, Frei B, Kulhanek D, Nowlin J, Quinn JF (2003) Prevention of age-related spatial memory deficits in a transgenic mouse model of Alzheimer's disease by chronic Ginkgo biloba treatment. Exp Neurol 184:510-520.

Stepanichev MY, Onufriev MV, Yakovlev AA, Khrenov AI, Peregud DI, Vorontsova ON, Lazareva NA, Gulyaeva NV (2008) Amyloid- $\beta(25-35)$ increases activity of neuronal NO-synthase in rat brain. Neurochem Int 52:1114-1124.

Sultana R, Butterfield DA (2009) Oxidatively modified, mitochondriarelevant brain proteins in subjects with Alzheimer disease and mild cognitive impairment. J Bioenerg Biomembr 41:441-446.

Sultana R, Poon HF, Cai J, Pierce WM, Merchant M, Klein JB, Markesbery WR, Butterfield DA (2006a) Identification of nitrated proteins in Alzheimer's disease brain using a redox proteomics approach. Neurobiol Dis 22:76-87.

Sultana R, Boyd-Kimball D, Poon HF, Cai J, Pierce WM, Klein JB, Merchant M, Markesbery WR, Butterfield DA (2006b) Redox proteomics identification of oxidized proteins in Alzheimer's disease hippocampus and cerebellum: an approach to understand pathological and biochemical alterations in AD. Neurobiol Aging 27:1564-1576.

Supinski GS, Murphy MP, Callahan LA (2009) MitoQ administration prevents endotoxin-induced cardiac dysfunction. Am J Physiol Regul Integr Comp Physiol 297:R1095-R1102.

Swerdlow RH, Khan SM (2009) The Alzheimer's disease mitochondrial cascade hypothesis: an update. Exp Neurol 218:308-315.

Takadera T, Sakura N, Mohri T, Hashimoto T (1993) Toxic effect of $\beta$-amyloid peptide ( $\beta 22-25)$ on hippocampal neuron and its prevention. Neurosci Lett 161:41-44.

Takuma K, Yao J, Huang J, Xu H, Chen X, Luddy J, Trillat AC, Stern DM, Arancio O, Yan SS (2005) ABAD enhances $A \beta$-induced cell stress via mitochondrial dysfunction. FASEB J 19:597-598.

Takuma K, Fang F, Zhang W, Yan S, Fukuzaki E, Du H, Sosunov A, McKhann G, Funatsu Y, Nakamichi N, Nagai T, Mizoguchi H, Ibi D, Hori O, Ogawa S, Stern DM, Yamada K, Yan SS (2009) RAGE-mediated signaling contributes to intraneuronal transport of amyloid- $\beta$ and neuronal dysfunction. Proc Natl Acad Sci USA 106:20021-20026.

Tamagno E, Bardini P, Obbili A, Vitali A, Borghi R, Zaccheo D, Pronzato MA, Danni O, Smith MA, Perry G, Tabaton M (2002) Oxidative stress increases expression and activity of BACE in NT2 neurons. Neurobiol Dis 10:279-288.

Tamagno E, Parola M, Bardini P, Piccini A, Borghi R, Guglielmotto M, Santoro G, Davit A, Danni O, Smith MA, Perry G, Tabaton M (2005) Betasite APP cleaving enzyme up-regulation induced by 4 -hydroxynonenal is mediated by stress-activated protein kinase pathways. J Neurochem 92:628-636.

Tong Y, Zhou W, Fung V, Christensen MA, Qing H, Sun X, Song W (2005) Oxidative stress potentiates BACE1 gene expression and A generation. J Neural Transm 112:455-469.

Turrens JF (1997) Superoxide production by the mitochondrial respiratory chain. Biosci Rep 17:3-8.

Velliquette RA, O'Connor T, Vassar R (2005) Energy inhibition elevates $\beta$-secretase levels and activity and is potentially amyloidogenic in APP 
transgenic mice: possible early events in Alzheimer's disease pathogenesis. J Neurosci 25:10874-10883.

Vorhees CV, Williams MT (2006) Morris water maze: procedures for assessing spatial and related forms of learning and memory. Nat Protoc $1: 848-858$.

Walhovd KB, Fjell AM, Brewer J, McEvoy LK, Fennema-Notestine C, Hagler DJ Jr, Jennings RG, Karow D, Dale AM; Alzheimer's Disease Neuroimaging Initiative (2010) Combining MR imaging, positron-emission tomography, and CSF biomarkers in the diagnosis and prognosis of Alzheimer disease. Am J Neuroradiol 31:347-354.

Wang J, Ho L, Zhao W, Ono K, Rosensweig C, Chen L, Humala N, Teplow DB, Pasinetti GM (2008a) Grape-derived polyphenolics prevent A $\beta$ oligomerization and attenuate cognitive deterioration in a mouse model of Alzheimer's disease. J Neurosci 28:6388-6392.

Wang X, Su B, Siedlak SL, Moreira PI, Fujioka H, Wang Y, Casadesus G, Zhu $\mathrm{X}$ (2008b) Amyloid- $\beta$ overproduction causes abnormal mitochondrial dynamics via differential modulation of mitochondrial fission/fusion proteins. Proc Natl Acad Sci USA 105:19318-19323.

Yanker BA, Duffy LK, Kirschner DA (1990) Neurotrophic and neurotoxic effects of amyloid beta protein: reversal by tachykinin neuropeptides. Science 12:279-282.

Yao J, Irwin RW, Zhao L, Nilsen J, Hamilton RT, Brinton RD (2009) Mitochondrial bioenergetic deficit precedes Alzheimer's pathology in female mouse model of Alzheimer's disease. Proc Natl Acad Sci USA 106:14670-14675.

Zhang Q, Yang G, Li W, Fan Z, Sun A, Luo J, Ke ZJ (2011) Thiamine deficiency increases $\beta$-secretase activity and accumulation of $\beta$-amyloid peptides. Neurobiol Aging 32:42-53.

Zhao XL, Wang WA, Tan JX, Huang JK, Zhang X, Zhang BZ, Wang YH, YangCheng HY, Zhu HL, Sun XJ, Huang FD (2010) Expression of $\beta$-amyloid induced age-dependent presynaptic and axonal changes in Drosophila. J Neurosci 30:1512-1522. 